\title{
Banks response to higher capital requirements: evidence from a quasi-natural experiment
}

\author{
Gropp, Reint ; Mosk, Thomas ; Wix, Carlo ; Ongena, Steven
}

\begin{abstract}
We study the impact of higher capital requirements on banks' balance sheets and its transmission to the real economy. The 2011 EBA capital exercise is an almost ideal quasi-natural experiment to identify this impact with a difference-in-differences matching estimator. We find that treated banks increase their capital ratios by reducing their risk-weighted assets and - consistent with debt overhang not by raising their levels of equity. Banks reduce lending to corporate and retail customers, resulting in lower asset-, investment- and sales growth for firms obtaining a larger share of their bank credit from the treated banks.
\end{abstract}

DOI: https://doi.org/10.1093/rfs/hhy052

Posted at the Zurich Open Repository and Archive, University of Zurich ZORA URL: https://doi.org/10.5167/uzh-175943

Journal Article

Accepted Version

Originally published at:

Gropp, Reint; Mosk, Thomas; Wix, Carlo; Ongena, Steven (2019). Banks response to higher capital requirements: evidence from a quasi-natural experiment. Review of Financial Studies, 32(1):266-299.

DOI: https://doi.org/10.1093/rfs/hhy052 


\title{
Bank Response To Higher Capital Requirements: Evidence From A Quasi-Natural Experiment
}

First version: November 2015

This version: March 2018

\begin{abstract}
We study the impact of higher capital requirements on banks' balance sheets and its transmission to the real economy. The 2011 EBA capital exercise is an almost ideal quasi-natural experiment to identify this impact with a difference-in-differences matching estimator. We find that treated banks increase their capital ratios by reducing their risk-weighted assets and - consistent with debt overhang - not by raising their levels of equity. Banks reduce lending to corporate and retail customers, resulting in lower asset-, investment- and sales growth for firms obtaining a larger share of their bank credit from the treated banks.
\end{abstract}


Basel III, which will become fully effective in 2019, significantly increases capital requirements for banks. However, at this point, the economic implications of such higher capital requirements are still unclear. Banks can, in principle, increase their regulatory capital ratios in two different ways: they can either increase their levels of regulatory capital (the numerator of the capital ratio) or they can shrink their risk-weighted assets (the denominator of the capital ratio) (Admati, DeMarzo, Hellwig, and Pfleiderer, 2017). While raising capital is generally considered "good deleveraging" by regulators, shrinking assets has potentially adverse effects if many banks simultaneously engage in cutting lending (Hanson, Kashyap, and Stein, 2011). How banks adjust their balance sheets in response to higher capital requirements is thus an empirical question of crucial importance to understand the real implications of higher capital requirements.

The empirical identification of the effect of higher capital requirements on banks' behavior faces a number of challenges. The most important challenge is to find exogenous variation in capital requirements. Yet, capital requirements tend to vary little over time, and when they do change, they change for all banks in a given economic area at the same time, leaving no crosssectional variation to exploit. In the case when supervisors make use of discretion and impose bank-specific requirements, they will be correlated with (unobserved) bank characteristics and thus not be exogenous with regard to banks' balance sheets. Finally, in order to assess the effects of capital requirements on bank lending, one needs to disentangle credit supply from credit demand.

We address these empirical challenges by exploiting the 2011 capital exercise, conducted by the European Banking Authority (EBA), as a quasi-natural experiment. The capital exercise required a subset of European banks to reach and maintain a $9 \%$ core tier 1 capital ratio by the end of June 2012. ${ }^{1}$ The institutional features of the capital exercise are particularly well-suited to address the above mentioned empirical challenges. First, the required core tier 1 ratio of $9 \%$ constituted an economically significant increase in capital requirements compared to the previously required $5 \%$. Second, the rule by which banks were selected into the capital exercise allows us to disentangle the effect of capital requirements from effects associated with bank size. The EBA used a countryspecific selection rule and included banks "in descending order of their market shares by total assets in each Member State" such that the exercise covered " $50 \%$ of the national banking sectors

\footnotetext{
${ }^{1} \mathrm{~A}$ bank's core tier 1 capital ratio is defined as its core tier 1 capital over its risk-weighted assets, with core tier 1 capital comprising only the highest quality capital instruments (common equity), disclosed reserves and hybrid instruments provided by governments (EBA, 2011c).
} 
in each EU Member State" (EBA, 2011a). Since national banking sectors in Europe differ with regard to their total size, this country-specific selection threshold yielded a considerable overlap in size between banks selected and not selected into the exercise. Moreover, the explicit selection rule based on bank size implies that selection into the capital exercise was based on observable bank characteristics. We exploit this exogenous variation in the bank selection rule and employ a difference-in-differences matching estimation approach to examine how banks subject to higher capital requirements adjust their balance sheets compared to otherwise similar banks not subject to a change in capital requirements.

Our main findings are as follows. First, we document that Capital Exercise banks (our treatment group) raised their core tier 1 capital ratios by 1.9 percentage points more compared to banks not subject to the higher capital requirements (the control group). Capital Exercise banks achieved this by reducing their levels of risk-weighted assets (RWA) by 16 percentage points. The control group is crucial for uncovering this finding: Capital Exercise banks increased their levels of core tier 1 capital by $19 \%$ over our sample period, but the control group raised their levels of core tier 1 capital by the same magnitude.

We then investigate in detail how banks adjust both the asset- and liability side of their balance sheets in response to higher capital requirements. To study the effect on banks' balance sheet composition, we hand-collect information about banks' exposures to different asset classes from the banks' Pillar 3 disclosure reports. We find that treated banks mainly reduced their exposures to corporate and retail borrowers. In further tests, we show that Capital Exercise banks reduced their risk-weighted assets relative to the control group by engaging in asset shrinking rather than risk reduction. These results suggest that banks are reluctant to issue new equity to increase their capital ratios when required to do so by regulators. Potential explanations include asymmetric information and debt overhang. Admati, DeMarzo, Hellwig, and Pfleiderer (2017) show that, in particular, banks with a large amount of outstanding subordinated debt should prefer asset sales to new equity issuances in the face of higher capital requirements. In line with this prediction, we show that Capital Exercise banks with an above median amount of subordinated debt are more likely to shrink their assets and retire subordinated debt.

Simply observing a reduction in outstanding customer loans on banks' balance sheets is, however, not sufficient to conclude that the supply of credit by Capital Exercise banks contracted, 
since this might very well just reflect a reduction in credit demand by firms borrowing from Capital Exercise banks. To disentangle credit supply from credit demand, we use syndicated loan data and exploit the presence of multiple bank-firm relationships to control for credit demand. Specifically, we employ a modified version of the Khwaja and Mian (2008) estimator, which estimates the change in outstanding syndicated loans of a bank to country-industry firm clusters. We show that Capital Exercise banks reduced their credit supply of syndicated loans by 17 percentage points relative to banks in the control group.

Ultimately, the degree to which a reduction in credit supply from Capital Exercise banks implies real effects at the firm level depends on the extent to which other banks, not subject to higher capital requirements, "pick up the slack". We thus study, in a final step, whether the reduction in lending by Capital Exercise banks had real effects on firms. We find that firms with an initial high share of loans from Capital Exercise banks exhibited 4 percentage points lower asset growth, 6 percentage points lower investment growth, and 5 percentage points lower sales growth than firms less reliant on funding from Capital Exercise banks. This result is driven by unlisted firms which are less likely to substitute a reduction in credit supply with other sources of funding.

These results suggest that the 2011 EBA capital exercise had a detrimental impact on bank lending in Europe with adverse effects for the real economy, confirming concerns about a policyinduced credit crunch raised in advance by Acharya, Schoenmaker, and Steffen (2011) amongst others. Our findings therefore have important policy implications for bank capital regulation: If regulators (such as the EBA in the 2011 capital exercise) impose an increase in capital requirements on short notice and focus on capital ratios as the policy target variable, then banks will choose to deleverage via shrinking assets rather than via raising new equity. As suggested by Hanson, Kashyap, and Stein (2011), targeting the absolute amount of new capital that has to be raised instead of targeting the capital ratio could mitigate this problem, an approach which has been successfully applied in the U.S. stress test conducted in 2009 (Hirtle, Schuermann, and Stiroh, 2009).

Our paper is most closely related to the literature examining the effect of shocks to banks' capital on bank lending. Peek and Rosengren (1997) exploit an exogenous shock to bank capital without a change in capital requirements to indirectly infer the effect on lending when capital requirements become binding. Another strand of literature seeks to directly exploit changes in 
capital requirements. An early study by Berger and Udell (1994) investigates bank lending before and after the introduction of Basel II, but without the benefit of exogenous cross-sectional variation in capital requirements. ${ }^{2}$ To alleviate this concern, Kashyap, Stein, and Hanson (2010) adopt a model-based calibration approach for the U.S., Fraisse, Lé, and Thesmar (2017) exploit variation in capital requirements across banks in France due to the use of internal risk models, Jimenéz, Ongena, Peydró, and Saurina (2017) analyze the introduction and later modifications in dynamic provisioning requirements in Spain, and Kisin and Manela (2016) estimate the shadow cost of capital requirements by exploiting a costly loophole that allowed banks in the U.S. to relax these constraints. Célérier, Kick, and Ongena (2016) explore the impact on lending in Germany by banks affected by tax reforms in Italy (in 2000) and Belgium (in 2006) which decreased their cost of bank equity. Finally, Mésonnier and Monks (2015) also exploit the EBA capital exercise and find that this regulatory event induced a credit crunch in the Euro Area.

We contribute to this literature in several ways. First, while most papers in the literature (with the exception of Mésonnier and Monks (2015)) study single-country settings, we exploit the country-specific bank selection rule of the 2011 EBA capital exercise to uniquely identify the effects of higher capital requirements across 18 countries. Second, our paper does not exclusively focus on lending, but investigates in detail how banks adjust both the asset- and liability side of their balance sheets in response to an increase in capital requirements. Third, we examine why banks are reluctant to issue equity. We provide novel empirical evidence for the recent theoretical prediction by Admati, DeMarzo, Hellwig, and Pfleiderer (2017) that banks' existing shareholders prefer to increase capital ratios by reducing assets rather than by raising new capital if banks can repurchase subordinated debt. Finally, we study the transmission of banks' balance sheet adjustments to the real economy in a multi-country setting and assess the resulting real effects on firms across Europe.

\section{The 2011 EBA Capital Exercise}

This section describes the objective and institutional details of the EBA capital exercise, which was announced by the EBA on October 26, 2011 (see Figure 1). The objective of the exercise was to restore confidence in the EU banking sector by ensuring that banks had sufficient capital

\footnotetext{
${ }^{2}$ More recently, Aiyar, Calomiris, Hooley, Korniyenko, and Wieladek (2014), De Marco and Wieladek (2015), and Jensen (2015) exploit changes in bank-specific capital requirements in the U.K. and Denmark, respectively.
} 
to insure against unexpected losses. To achieve this objective, the EBA required 61 banks to build up additional capital buffers to reach a $9 \%$ core tier 1 ratio by the end of June 2012 . The capital exercise was an official "Recommendation" issued by the EBA. According to article 16(3) of the EBA regulation as established by the European Parliament, national supervisory authorities must make every effort to comply with the "Recommendation". The EBA capital exercise did not coincide with other changes in capital requirements for European banks. In particular, the EU only started with the gradual introduction of Basel III in 2013 (Capital Requirements Directive IV). After the capital exercise, the EBA kept monitoring banks' compliance with the $9 \%$ core tier 1 ratio.

[Figure 1 about here]

Both the timing and magnitude of this increase in capital requirements was unexpected. The capital exercise came only a few months after the EBA stress test in June 2011 and was described as a "quick-fire regulatory health check". ${ }^{3}$ The Financial Times reported that the $9 \%$ requirement was "well beyond the current expectations of banks and analysts." 4 The credibility and rigor of the June stress test had been criticized, in particular because the Belgian bank Dexia was declared in the stress test to be one of the safest banks in Europe, but had failed less than three months later (Greenlaw, Kashyap, Schoenholtz, and Shin, 2012). Although both the EBA stress test and the subsequent EBA capital exercise increased capital requirements for Capital Exercise banks in 2011, the estimated 115 billion Euro capital shortfall due to the capital exercise dwarfed the 2.5 billion Euro capital shortfall due to the stress test (Acharya, Engle, and Pierret, 2014). Thus, we naturally focus on the EBA capital exercise as the singularly overriding regulatory intervention.

The 61 Capital Exercise banks were selected based on total assets. In each country, the EBA included "banks in descending order of their market shares by total assets", such that the exercise covered "at least $50 \%$ of the national banking sectors in each EU Member State in terms of total consolidated assets as of end of 2010" EBA (2011a). ${ }^{5}$ As in the 2011 EBA stress test, selection

\footnotetext{
3 "Exclusive: Europe hits banks with tougher capital test", by Philipp Halstrick and Andreas Framke, Reuters, October 11, 2011.

4 "Europe's banks face 9\% capital rule", by Patrick Jenkins, Ralph Atkins, and Peter Spiegel, Financial Times, October 11, 2011.

${ }^{5}$ From the initial 71 banks, the EBA excluded during the capital exercise banks which were "undergoing a deep restructuring", namely Dexia, Österreichische Volksbank AG, West LB, all six Greek banks (EFG Eurobank Ergasias S.A., National Bank of Greece, Alpha Bank, Piraeus Bank Group, Agricultural Bank of Greece (ATE bank), TT Hellenic Postbank S.A.) and Bankia. We do not include these banks in the analysis.
} 
into the capital exercise was based on total assets as of end of 2010 and selection was therefore not based on bank-specific events in the months prior to the capital exercise.

Capital Exercise banks were asked to submit their recapitalization plans to their respective national authorities outlining how they intended to reach the set targets. The EBA recommended that "banks should first use private sources of funding to strengthen their capital position to meet the required target, including retained earnings, reduced bonus payments, new issuances of common equity and suitably strong contingent capital, and other liability management measures." The EBA also stressed that "reductions in risk-weighted assets due to the validation [...] should not, in general, be allowed as a means of addressing a capital shortfall unless these changes are already planned and under consideration by the competent authority" (EBA, 2011b). However, the EBA also left discretion to the national supervisors which measures to take to enforce the higher capital requirements. ${ }^{6}$ In addition, the EBA did not specify how they would enforce their recommendations how to recapitalize.

\section{Empirical Strategy and Data}

This paper exploits the 2011 EBA capital exercise to identify how banks adjust their balance sheets in response to higher capital requirements and how this adjustment process affects firms which obtain a substantial share of their borrowing from these banks. Hence, we first analyze at the bank level the extent to which the exercise changed bank behavior. Next, we move to the individual loan level to disentangle credit supply from credit demand. Finally, we examine the effect of higher bank capital requirements on asset-, investment-, and sales growth at the firm level.

\section{A. Bank-Level Analysis}

The setup of the capital exercise, whereby the EBA reviewed a subset of banks' actual capital positions and sovereign exposures and "requested them (i.e., our treatment group) to set aside additional capital buffers" (EBA, 2011c), while leaving requirements unchanged for other European

\footnotetext{
${ }^{6}$ For example: "National supervisory authorities may, following consultation with the EBA, agree to the partial achievement of the target by the sales of selected assets that do not lead to a reduced flow of lending to the EU's real economy but simply to a transfer of contracts or business units to a third party" (EBA, 2011b). In contrast, the 2009 U.S. Supervisory Capital Assessment Program (SCAP) strictly required banks "to raise additional capital, either in public markets or by issuing mandatory convertible preferred securities" (Hirtle, Schuermann, and Stiroh, 2009).
} 
banks (i.e., our pool of control group banks), naturally lends itself to a difference-in-differences research design. However, selection into the capital exercise was not random. Instead, the EBA selected banks according to an explicit selection rule based on bank size, resulting in Capital Exercise banks being on average larger than Non-Capital Exercise banks. This would compromise any causal inference if large banks would differ from small banks, for example in terms of business models or funding strategies, and would exhibit different trends even in the absence of a change in capital requirements. ${ }^{7}$ We exploit the country-specific selection threshold of the EBA selection rule in various ways to address this potential selection problem. Figure 2 shows the size distribution of Capital Exercise banks and Non-Capital Exercise banks across different countries. While Capital Exercise banks are on average larger than Non-Capital Exercise banks, the country-specific selection threshold yields a considerable size overlap between banks selected and not selected into the capital exercise. For example, while the smallest bank included in the EBA capital exercise, the Slovenian bank Nova Kreditna banka Maribor, had 6 billion euro in total assets as of end of 2010, the largest European bank not included in the capital exercise, the French bank Crédit Mutuel, had 591 billion euro in total assets in the same year. Knowledge about the selection rule based on observable characteristics (total assets) in combination with an overlap in size allows us to combine the difference-in-differences framework with an appropriate matching methodology by matching banks from the treatment group to similar banks from the pool of control group banks.

[Figure 2 about here]

The paper uses the bias-corrected Abadie and Imbens (2002) matching estimator, which has recently been used by Almeida, Campello, Laranjeira, and Weisbenner (2011), Campello and Giambona (2013) and Kahle and Stulz (2013) in a corporate finance setting. ${ }^{8}$ To alleviate concerns that our results are driven by bank characteristics other than size, this paper also matches on

\footnotetext{
${ }^{7}$ The empirical setting of the capital exercise also seems to lend itself to a regression discontinuity design (RDD). Certain aspects of the empirical setting, however, preclude this approach from being the appropriate methodology. In the Online Appendix, we report the RDD estimation results in Table A5 and discuss the limitations of this approach due to the existence of multiple country-specific thresholds.

${ }^{8}$ Figure 2 also shows that while the distributions of total assets overlap, they are significantly different. If the covariate distributions differ substantially, conventional regression methods can be sensitive to minor specification changes because of their heavy reliance on extrapolation of regions where there is no support in the data (Imbens, 2014). One approach to address this problem is the matching estimator developed by Abadie and Imbens (2002). Table A4 in the Online Appendix reports the results of the bank-level part of the paper using a regression-based approach.
} 
pre-treatment levels of the core tier 1 ratio, customer loans as a share of total assets, net interest income as a share of total operating revenue, depository funding as a share of total assets, and net income over total assets. These matching covariates capture potential differences in the capital structure, business models, funding strategies, and profitability of similarly sized banks prior to the capital exercise.

We adopt four different matching strategies, each exploiting the EBA's selection rule in a different way and each addressing a different identification concern. The full sample matching strategy matches four Non-Capital Exercise banks to each Capital Exercise bank based on the six matching covariates using the full sample of 48 Capital Exercise banks and 144 Non-Capital Exercise banks. ${ }^{9}$ Second, we match Capital Exercise banks to Non-Capital Exercise banks in the "overlap sample" of banks which are larger than the smallest Capital Exercise bank and smaller than the largest Non-Capital Exercise bank. This overlap matching strategy completely removes the remaining size difference between Capital Exercise banks and Non-Capital Exercise banks and rules out that our results are driven by bank size. Third, we match Capital Exercise banks to Non-Capital Exercise banks around the selection threshold within the same country. Therefore, we construct a "threshold sample" which includes the two smallest Capital Exercise banks and the two largest Non-Capital Exercise banks within each country. This within country matching strategy specifically addresses concerns that our results are driven by cross-country differences, such as regulatory interventions and different business cycles. Finally, we use the "threshold sample" and match Capital Exercise banks to Non-Capital Exercise banks around the selection threshold within the same region (GIIPS countries and Non-GIIPS countries). This within region matching strategy addresses the concern that our results are driven by the European sovereign debt crisis, which mainly affected banks in GIIPS countries (Acharya, Eisert, Eufinger, and Hirsch, 2016). For all four matching strategies, we estimate the average treatment effect on the treated (ATT) on banks outcomes using the bias-corrected Abadie and Imbens (2002) matching estimator. Table I provides an overview of our four matching strategies.

[Table I about here]

\footnotetext{
${ }^{9}$ Regarding the number of matches, we follow Abadie and Imbens (2011) and choose four matches, which was found to be a good trade-off between the bias (which is increasing in the number of matches) and the variance (decreasing in the number of matches) of the matching estimator.
} 
For the bank-level part of the paper, we use annual bank balance sheet data from the SNL Financial Company database. Our initial sample contains all 61 Capital Exercise banks and all 494 Non-Capital Exercise European commercial and savings banks from the SNL Financial universe. Since the EBA capital exercise was conducted at the highest level of consolidation, we exclude all subsidiaries of Capital Exercise banks, Non-Capital Exercise banks, and foreign banks. As the paper wants to track the behavior of independent banks over time, we also exclude all banks which were acquired during the sample period, all banks which received capital injections during the pretreatment period and all banks with negative levels of equity. This sample construction procedure finally leaves us with a sample of 48 Capital Exercise banks and 144 Non-Capital Exercise banks. ${ }^{10}$ The sample period spans two post-treatment years after the capital exercise (2012 and 2013) and a symmetrical time window of two pre-treatment years prior to the capital exercise (2009 and 2010).

To investigate how higher capital requirements affect the composition of banks' lending portfolios, we hand-collect the components of credit risk-weighted assets from the banks' Pillar 3 disclosure reports for the years 2009, 2010, 2012 and 2013 from the banks' websites and use these data to investigate for which exposure classes (corporate, retail, sovereign) banks adjust their credit riskweighted assets. Panel A of Table II provides the summary statistics of all dependent variables used in the bank-level part for the full sample.

[Table II about here]

\section{B. Loan-Level Analysis}

While bank balance sheet data is appropriate for investigating how banks adjust their balance sheets in response to higher capital requirements, it is not suitable for identifying the effect on bank lending. In particular, by using bank balance sheet data one cannot disentangle credit supply from credit demand. Thus, to study the effect of higher capital requirements on banks' credit supply, we use loan-level data on syndicated loans and, for identification, exploit multiple bankfirm relationships in the spirit of Khwaja and Mian (2008). As syndicated loans often have long maturities, bank exposures to individual firms are therefore often constant over time. We thus modify the estimator similar to Popov and Van Horen (2015) and Acharya, Eisert, Eufinger, and

\footnotetext{
${ }^{10}$ Table A1 in the Online Appendix lists all Capital Exercise banks in our sample.
} 
Hirsch (2016) and aggregate firms into clusters based on their industry and country of incorporation. By clustering at the country-industry level, we ensure that firms are subject to the same regional and sectoral shocks over time and we attribute the remaining variation in loan exposure volumes to a reduction in credit supply.

We then estimate the following difference-in-differences regression specification:

$$
\Delta \log \text { Loan Exposure } \text { Eij }=\beta \cdot \mathrm{CEB}_{b i}+\gamma \cdot X_{b i}+\eta_{i}+\eta_{j}+\epsilon_{b i j}
$$

where $\Delta \log$ Loan Exposure Eij $_{\text {is }}$ is the change in loan exposures of bank $b$ in country $i$ to firm cluster $j$ between the four quarters before the EBA capital exercise (2010Q3 - 2011Q2) and the four quarters after the capital exercise (2012Q3 - 2013Q2). ${ }^{11}$ The variable $C E B_{b i}$ takes on the value of 1 if the bank is a Capital Exercise bank, and 0 otherwise. In addition, the specification includes bank characteristics as of 2010 (log total assets, core tier 1 ratio, customer loans as a share of total assets, net interest income as a share of total operating revenue, depository funding as a share of total assets, and net income over total assets); firm-cluster fixed effects $\eta_{j}$, which absorb all cluster-specific credit demand shocks; and fixed effects for banks' home countries, $\eta_{i}$, to absorb shocks which affect all banks in a given country. Like Khwaja and Mian (2008), we follow Bertrand, Duflo, and Mullainathan (2004) and collapse our data into a single pre- and a single post-treatment period before differencing to produce standard errors that are robust to concerns of autocorrelation. In addition, standard errors are clustered at the bank level.

For the loan-level part of the paper, we obtain data from Thomson Reuters LPC's Dealscan database, which contains detailed information on syndicated loan contract terms, loan types, and maturities. We collect data on all outstanding term loans and credit lines from banks in our sample to non-financial corporate borrowers incorporated in EBA countries. ${ }^{12}$ Of the 76 banks in our matched control group, 63 were active in the syndicated loan market during our sample period and are feasible to serve as control group banks in the loan-level part of the paper. Dealscan contains full information on the loan allocation between syndicate members for about $32 \%$ of all

\footnotetext{
${ }^{11}$ Our analysis investigates a time window of four quarters after the capital exercise (2012Q3-2013Q2) and thus focuses on the short-run adjustments of banks' credit supply in response to higher capital requirements. While a full-fledged analysis of the long-run effects of higher capital requirements is beyond the scope of this paper, we explore such potential long-run adjustments in Table A11 and Figure A4 in the Online Appendix.

${ }^{12}$ For term loans and credit lines, we follow the variable definition of Berg, Saunders, and Steffen (2016).
} 
loans. For the remaining 68\%, we follow De Haas and Van Horen (2012) and divide the loan facility equally among all members of a syndicate. Our initial sample contains 10,829 syndicated loans from 109 banks to 5,693 companies. The LPC Dealscan database contains the issuance of new syndicated loans at the time of origination. To employ our modified version of the Khwaja and Mian (2008) estimator, we transform the data and calculate the outstanding exposure of bank $b$ in country $i$ to firm cluster $j$ in quarter $q$ using the maturity variable contained in the database. In our main analysis, we focus on the intensive margin sample which includes only country-industry firm clusters to which Capital Exercise banks lend both before and after the capital exercise. Thus, this sample excludes country-industry firm clusters that entirely stop borrowing after or do not borrow prior to the capital exercise. The intensive margin sample includes 45 Capital Exercise banks and 27 Non-Capital Exercise banks. ${ }^{13}$ Panel B of Table II provides the summary statistics of all dependent variables used in the loan-level part for the full sample.

\section{Firm-Level Analysis}

In the final empirical step, we link the Capital Exercise banks' balance sheet adjustments to real outcomes at the firm level. A reduction in credit supply of Capital Exercise banks would not necessarily yield effects at the firm level if other banks, not subject to an increase in capital requirements, would pick up the slack. An increase in capital requirements for the subset of Capital Exercise banks would then not affect the total supply of credit to the real economy and would not affect firms' corporate policies.

To measure a firm $j$ 's dependence on credit supply from Capital Exercise banks (CEB) prior to the capital exercise, we construct the variable CEB Borrowing Share:

$$
\text { CEB Borrowing Share }{ }_{j}=\frac{\sum_{i[C E B]} \frac{1}{4} \sum_{q=2010 Q 3}^{2011 Q 2} \text { OutstandingLoans }_{i j q}}{\sum_{i[\text { AllBanks }]} \frac{1}{4} \sum_{q=2010 Q 3}^{2011 Q 2} \text { OutstandingLoans } s_{i j q}}
$$

where the numerator is the average amount of outstanding loans of firm $j$ obtained from Capital Exercise banks over the four quarters prior to the capital exercise (2010Q3 - 2011Q2) and the denominator is the average amount of total outstanding loans of firm $j$ obtained from all banks over the same period. For firms in our sample which were not borrowing in the syndicated loan

\footnotetext{
${ }^{13}$ In Table A14 in the Online Appendix, we provide additional results on the extensive margin sample of firms
} 
market in the period before the capital exercise (but in the period after the capital exercise), we assign a CEB borrowing share of zero, since those firms were not dependent on credit from Capital Exercise banks prior to the capital exercise. In the bank- and loan-level part, we restrict our analysis to banks from EBA countries. Since European firms might also borrow from banks incorporated in Non-European countries, we now also include those banks when computing the CEB borrowing share. We then divide our sample of firms into "Capital Exercise bank (CEB) dependent firms" with an above median dependence on credit supply from Capital Exercise banks as measured by the CEB borrowing share (our treatment group), and "Non-CEB dependent firms" with a below median dependence on credit supply from Capital Exercise banks (our control group pool). Since CEB dependent firms might differ from Non-CEB dependent firms along a number of important characteristics, we employ a difference-in-differences matching methodology analog to the one used in the bank-level part. We match firms on country of incorporation, industry as defined by the 1digit SIC code, whether the firm is publicly listed or not, and pre-treatment levels of the logarithm of total assets, tangibility, cash flow over total assets, net worth, EBITDA over total assets, and leverage. ${ }^{14}$

As in the bank-level part of the paper, we estimate the treatment effect on the treated (ATT) using the Abadie and Imbens (2002) bias-corrected matching estimator. ${ }^{15}$ The main outcome variables are the change in the logarithms of total assets, fixed assets (as a measure of investment, following Campello and Larrain (2016)), and sales between the period before the capital exercise (2009 and 2010) and after the capital exercise (2012 and 2013). All variables are winsorized at the $5 \%$ level. ${ }^{16}$ As we expect results to be stronger for firms which are less likely to substitute a reduction in credit supply with other sources of funding (e.g., issuing equity), we also split our sample into listed and unlisted firms and report results separately.

For the firm-level part of the paper, we use information on firms' balance sheets and profit and loss statements from Bureau van Dijk's Amadeus Financials database. The database additionally contains information on a firm's country of incorporation, its SIC industry code, and whether the firm is publicly listed. We have access to the sample of firms classified as Very Large, Large, and

\footnotetext{
${ }^{14}$ The definitions of all variables are summarized in Table A2 in the Online Appendix.

${ }^{15}$ Table A15 in the Online Appendix additionally reports results of a difference-in-differences regression analysis.

${ }^{16}$ Regarding the level of winsorization we follow Acharya, Eisert, Eufinger, and Hirsch (2016). In unreported robustness tests, we find similar results when winsorizing the variables at the $1 \%$ level.
} 
Medium-Sized by Amadeus. Since the Dealscan database and the Amadeus database share no common identifier, we hand-merge the two datasets and additionally require non-missing values on all relevant variables, which leaves us with a sample of 1,958 firms. Panel C of Table II provides the summary statistics of all dependent variables used in the firm level part for the full sample.

\section{Results}

\section{A. Bank-Level Results}

\section{A.1. Summary Statistics}

We first provide summary statistics before and after matching for the different matching strategies. Table III shows the pre-treatment mean values of the matching covariates for Capital Exercise banks, Non-Capital Exercise banks, and matched control group banks as of end of 2010, the year immediately prior to the capital exercise. We use Welch's t-test to test for differences in means between the groups.

\section{[Table III about here]}

Panel A of Table III compares the 48 Capital Exercise banks with 144 Non-Capital Exercise banks in the unmatched sample. As expected, Capital Exercise banks significantly differ from Non-Capital Exercise banks along a number of important dimensions. Due to the capital exercise being carried out on the largest banks in each country, the mean Capital Exercise bank is more than 18 times larger than the mean Non-Capital Exercise bank. The two groups of banks also significantly differ in terms of their business models, with the mean Capital Exercise bank being less engaged in customer lending and generating less of its revenue from interest income than the mean Non-Capital Exercise bank. Moreover, the mean Capital Exercise bank has a lower core tier 1 ratio and is significantly less reliant on customer deposits (i.e. more reliant on wholesale funding) than the mean Non-Capital Exercise bank. These large differences between Capital Exercise banks

and Non-Capital Exercise banks regarding important characteristics emphasize the necessity of employing a matching procedure.

Panel B of Table III shows the mean values of Capital Exercise banks and control group banks based on our full sample matching specification. This matching procedure significantly reduces 
the differences between Capital Exercise banks and Non-Capital Exercise banks, especially with regard to our measures for banks' business models. While Capital Exercise banks are still larger than matched control group banks, this matching procedure reduces the difference from Capital Exercise banks being more than 18 times larger to Capital Exercise banks being roughly 4 times larger. To address concerns that our results might be driven by bank size, we employ the overlap matching strategy. Panel C of Table III shows that this matching strategy reduces the size difference to 5 billion euro, which is statistically insignificant. Panel D of Table III shows the post-matching summary statistics for the within country matching strategy, which addresses concern that our results are driven by country-specific factors; and Panel E of Table III shows the post-matching summary statistics for the within region matching strategy, which specifically addresses the concern that our results are driven by the European sovereign debt crisis and banks from GIIPS countries. ${ }^{17}$

\section{A.2. Adjustment of Core Tier 1 Ratios}

We first examine whether Capital Exercise banks did indeed increase their core tier 1 ratios in response to higher capital requirements, and whether they did so via increasing their levels of capital (adjustment via the numerator) or via reducing risk-weighted assets (adjustment via the denominator). The underlying assumption of a difference-in-differences estimator requires that Capital Exercise banks and matched control group banks would follow a similar trend in absence of the treatment ("parallel trend assumption"). Figure 3 shows the evolution of mean core tier 1 ratios relative to 2010 for Capital Exercise banks and the matched control groups for each of the four matching strategies. Figure 4 and Figure 5 show the evolution of mean core tier 1 capital and mean risk-weighted assets relative to 2010, respectively. As can be seen in Panel A of Figure 3, both Capital Exercise banks and matched control group banks in the full sample increase their core tier 1 ratios up to 2010, the year immediately prior to the capital exercise. Starting in 2011, Capital Exercise banks begin to increase their core tier 1 ratios significantly more than banks in the matched control group. Moreover, a comparison of the extrapolated pre-treatment trends with the actual core tier 1 ratios shows that the Capital Exercise banks strongly diverge from their

\footnotetext{
${ }^{17}$ Although the matching strategies reduce the differences between the two groups of banks, some differences remain significant. To address this problem, we use the Abadie and Imbens (2002) bias-corrected matching estimator which introduces a bias-correction term to remove the bias in the coefficients stemming from imperfect matches on continuous covariates.
} 
pre-treatment trend after the capital exercise, while banks in the matched control group follow a fairly similar path in the post-treatment period. Panels B-D of Figure 3 show similar patterns for the other three matching strategies. As shown in Figure 4, Capital Exercise banks did not increase their core tier 1 ratios relative to the matched control groups by increasing their levels of core tier capital, but instead, as shown in Figure 5, by significantly reducing risk-weighted assets.

[Figure 3, Figure 4, and Figure 5 about here]

Table IV reports formal tests for the differences in pre-treatment trends between Capital Exercise banks and matched control group banks. As can be seen in Panel A, Capital Exercise banks increased their core tier 1 ratios significantly more than matched control group banks in the full sample over the period from 2008 to 2010 due to a higher reduction in risk-weighted assets over this period. Panels B-D of Table IV show that the overlap matching and within country matching strategies result in parallel pre-treatment trends for core tier 1 ratios, core tier 1 capital, and risk-weighted assets, as can also be seen in Panels B-D of Figure 4 and Figure 5. The advantage of these three matching strategies is that they result in a comparison of more similar banks than in the full sample, at the cost of a smaller sample size. Thus, we report all results of the bank-level analysis for both the full sample matching strategy and the overlap matching strategy. ${ }^{18}$

[Table IV about here]

Table V reports the estimation results for the changes in the core tier 1 ratios, in the logarithms of core tier 1 capital, and in the logarithms of risk-weighted assets from the period before to the period after the capital exercise between Capital Exercise banks and banks in the matched control groups. In each panel, Row 1 reports the before-after differences for Capital Exercise banks, Row 2 the before-after differences for matched control group banks, and Row 3 the bias-corrected Abadie and Imbens (2002) matching estimator for the average treatment effect on the treated (ATT). The first column of Panel A of Table V shows how both Capital Exercise banks and banks in the matched control group increased their core tier 1 ratios in the two years after the capital exercise, reflecting a general upward trend among European banks, which can also be seen in Figure 3. However, while

\footnotetext{
${ }^{18}$ For the sake of brevity, we report the results for the within country matching strategy and the within region matching strategy only for Section III.A.2. All other results are available from the authors upon request.
} 
matched control group banks increased their core tier 1 ratios by only 1.78 percentage points on average, Capital Exercise banks did so by 3.02 percentage points and thus significantly more than banks not subject to higher capital requirements. The ATT equals 1.86 percentage points and is significant at the $1 \%$ level, indicating that the increase in capital requirements did indeed affect the core tier 1 ratios of banks selected into the capital exercise.

[Table $\mathrm{V}$ about here]

The second column of Panel A of Table V shows that Capital Exercise banks increased their levels of core tier 1 capital by $19 \%$ around the 2011 EBA capital exercise. However, as the comparison with the matched control group indicates, this increase seems to reflect a general development in the European banking system rather than an effect of the capital exercise. European banks not selected into the capital exercise exhibited an almost identical percentage increase in their levels of core tier 1 capital, rendering the ATT insignificant. This finding provides evidence that Capital Exercise banks did not respond to the increase in capital requirements by raising new capital. In contrast, there is a significant difference in the change of risk-weighted assets between Capital Exercise banks and matched control group banks around the capital exercise, as can be seen in the third column of Panel A of Table V. While Capital Exercise banks reduced their levels of risk-weighted assets by 10 percentage points over the sample period, matched control group banks kept their levels of risk-weighted assets unchanged. The ATT indicates that Capital Exercise banks reduced their risk-weighted assets by 16 percentage points compared to banks in the matched control group which were not subject to an increase in capital requirements. ${ }^{19}$ The analog matching results of the overlap matching strategy in Panel B, the within country matching strategy in Panel C, and the within region matching strategy in Panel $\mathrm{D}$ of Table $\mathrm{V}$ show that our results are robust to concerns of bank size, country-specific factors, and exposure to the European sovereign debt crisis, respectively. ${ }^{20}$ In particular, the results of the within region matching strategy show that our results are not driven by the European sovereign debt crisis which started in 2010 and mainly affected the economies of Greece, Ireland, Italy, Portugal, and Spain (GIIPS countries). This suggests that

\footnotetext{
${ }^{19}$ In the Online Appendix in Table A8, we furthermore show that these results are driven by weakly capitalized banks.

${ }^{20}$ Note that in Table $\mathrm{V}$, the before-after differences do not always exactly add up to the ATT due to the biascorrection term introduced by the matching estimator. Figure A1 in the Online Appendix provides scatter plots of the dependent variables and shows that our results are not driven by a small number of outlier banks.
} 
our findings also have external validity in situations in which banks are not under any particular financial distress (as in northern Europe during our sample period). ${ }^{21}$ In all cases, the matching results suggest that Capital Exercise banks responded to the increase in capital requirements by reducing their risk-weighted assets compared to banks in the control group. The combined findings in Table $\mathrm{V}$ are the first central result of the bank-level analysis in our paper. They provide evidence that banks, when faced with an increase in capital requirements, adjust their capital ratios by reducing their levels of risk-weighted assets (adjustment via the denominator) rather than by raising new capital (adjustment via the numerator).

\section{A.3. Adjustment of Core Tier 1 Capital and Risk-Weighted Assets Components}

In this section, we study in detail the adjustments of the components of both core tier 1 capital and risk-weighted assets. ${ }^{22}$ We supplement the SNL data on the components of core tier 1 capital and risk-weighted assets by hand-collecting missing data from the banks' annual reports. Core tier 1 capital consists of tier 1 common equity (share capital and share premium plus retained earnings) and regulatory adjustments, which are deducted from tier 1 common equity. For example, goodwill and any other intangible assets are deducted from tier 1 common equity because of the high degree of uncertainty of their value in case of a default. Table VI shows that both Capital Exercise and matched control group banks increased their tier 1 common equity by increasing their retained earnings and share capital, although matched control group banks did this at a faster rate. Instead, Capital Exercise banks reduced their regulatory adjustments more than the matched control group. ${ }^{23}$

[Table VI about here]

A banks' risk-weighted assets consist of the risk-weighted assets for credit risk (cRWA), market risk (mRWA), and operational risk (oRWA). Table VI presents the results for this decomposition of

\footnotetext{
${ }^{21}$ Table A6 in the Online Appendix provides a further regression-based test which shows that our results are not driven by banks from GIIPS countries. Additionally, Table A7 in the Online Appendix provides a placebo test around the start of the crisis in 2010 which shows that Capital Exercise banks and matched control group banks exhibited a similar evolution in their levels of core tier 1 capital and risk-weighted assets during this placebo period.

${ }^{22}$ Table A3 in the Online Appendix shows a regulatory bank balance sheet and the decomposition of core tier 1 capital and risk-weighted assets used in this section.

${ }^{23}$ The accounting rules governing these regulatory adjustments allow banks to manage these deductions to maximize their core tier 1 capital. Using a sample of U.S. banks, Lubberink (2014) shows that banks do use these adjustments to increase their regulatory capital.
} 
risk-weighted assets and shows that Capital Exercise banks reduced their risk-weighted assets for credit risk. This implies that Capital Exercise banks adjusted their loan portfolio, instead of their trading portfolio. Using hand-collected data from the banks' Pillar 3 disclosure reports, we further decompose the risk-weighted assets for credit risk into credit risk-weighted assets for corporate exposures, retail exposures (incl. exposures to SMEs), and sovereign exposures. Table VI shows that the reduction in credit risk comes from a reduction in corporate and retail exposures.

[Table VII about here]

\section{A.4. Risk Reduction versus Asset Shrinking}

Banks could reduce risk-weighted assets by changing the composition of their corporate and retail portfolios from riskier assets into safer assets, by recalibrating their internal risk-weight models (Behn, Haselmann, and Vig, 2016), or by shrinking their assets. We construct two tests to examine which mechanism drives the reduction in risk-weighted assets. Both risk reduction and model recalibration would result in a lower average risk weight (Risk-Weighted Assets/Total Assets) while keeping total assets constant. Pure asset shrinking would result in a constant average risk weight and a drop in total assets. Table VIII reports the matching estimation results for two different measures of banks' asset risk as the outcome variable. The first column shows that there is no statistically significant difference in the changes of the RWA/TA ratio between Capital Exercise banks and banks in the matched control group. Similarly, the second column shows that there is also no significant treatment effect with regard to loan loss reserves relative to outstanding customer loans. These results show that Capital Exercise banks did not reduce their risk-weighted assets by engaging in risk reduction.

[Table VIII about here]

Instead, Column 3 of Table VIII shows that Capital Exercise banks reduced total assets by 14 percentage points compared to banks in the matched control group. Moreover, the matching estimator in Column 4 of Table VIII indicates that Capital Exercise banks reduced outstanding customer loans by 12 percentage points compared to the matched control group of banks not subject to an increase in capital requirements. Finally, we also document a negative treatment effect on 
security holdings of Capital Exercise banks. However, as customer loans make up $60 \%$ of the average Capital Exercise bank's balance sheet while security holdings only make up 27\%, the asset shrinking behavior of Capital Exercise banks can mainly be attributed to a relative reduction in outstanding customer loans.

\section{A.5. Why are Banks Reluctant to Raise Equity?}

We now turn to the question why banks are reluctant to raise equity. Potential explanations include debt overhang and asymmetric information. Admati, DeMarzo, Hellwig, and Pfleiderer (2017) show that if banks can repurchase subordinated debt, existing shareholders find it preferable to deleverage by shrinking assets and repurchasing subordinated debt rather than by issuing new equity. The economic mechanism behind Admati, DeMarzo, Hellwig, and Pfleiderer (2017) is a debt overhang problem: highly levered banks resist new equity issuances and may forgo positive NPV projects because the cash flows will accrue to debtholders. In a similar vein, Bahaj and Malherbe (2017) propose a theoretical model of bank behavior under capital requirements and also show that banks' lending response to an increase in capital requirements is more negative in the face of severe debt overhang.

A direct empirical implication of Admati, DeMarzo, Hellwig, and Pfleiderer (2017) is that banks with higher levels of subordinated debt prefer asset shrinking and the repurchase of subordinated debt over a pure recapitalization. ${ }^{24}$ We test this prediction by splitting our sample into banks with above and below median levels of subordinated debt (9.3\% hybrid securities and other subordinated debt of total debt) and separately study the effect of the capital exercise on the change in the core tier 1 ratio and its components in each subsample. Columns 1 to 3 of Table IX show that Capital Exercise banks with above median levels of subordinated debt increased their core tier 1 ratio by reducing risk-weighted assets, while Capital Exercise banks with below median levels increased their capital ratios by increasing their levels of core tier 1 capital. This empirical finding is in line with the theoretical predictions of both Admati, DeMarzo, Hellwig, and Pfleiderer (2017) and Bahaj and Malherbe (2017).

[Table IX about here]

\footnotetext{
${ }^{24}$ See Proposition 9 (Multiple Classes of Existing Debt) in Admati, DeMarzo, Hellwig, and Pfleiderer (2017).
} 
We furthermore test whether Capital Exercise banks with high levels of subordinated debt bought back their subordinated debt. ${ }^{25}$ The evidence is somewhat mixed. Column 4 of Table IX shows that while banks with high levels of subordinated debt reduce their holdings of subordinated debt by a large magnitude in the full sample, the coefficient is not significant, albeit large in magnitude, in the overlap sample.

Capital Exercise banks could also be reluctant to issue new equity due to asymmetric information concerns. If investors interpret a bank's decision to issue equity as a signal that the bank's stock is overvalued, then banks might want to avoid sending out such a negative signal. Moreover, in the presence of debt overhang, the issuance of new equity might lead to a wealth transfer from existing stockholders to bondholders. We would therefore like to test how equity issuances by Capital Exercise banks and Non-Capital Exercise banks affect the banks' stock and bond prices. We collect data on common equity issuances of banks in our sample from the SNL Capital Issuance Database and data on banks' stock and bond prices from Datastream. Yet, during the period of the capital exercise only 7 Capital Exercise banks and 6 control group banks announced equity issuances. Hence, it is difficult to draw strong conclusions from this analysis beyond the fact that seasoned equity issuances in the wake of the capital exercise were rare. However, the similar number of issuances between the two groups of banks provides additional evidence that any differential adjustment in core tier 1 ratios was unlikely to come from increases in the levels of equity. ${ }^{26}$

\section{B. Loan-Level Results}

To rule out that the reduction in outstanding customer loans of Capital Exercise banks shown in Section III.A is driven by demand effects, we employ a modified version of the Khwaja and Mian (2008) estimator, which estimates the change in outstanding syndicated loan volumes of Capital Exercise banks and control group banks to Country $\times$ Industry firm clusters (see Acharya, Eisert, Eufinger, and Hirsch (2016)). Figure 6 shows the trends in outstanding syndicated loan volumes for Capital Exercise banks and control group banks relative to 2011-Q2, the quarter immediately

\footnotetext{
${ }^{25}$ Vallée (2016) documents that numerous European banks bought back subordinated hybrid bonds trading under par value to strengthen their capitalizations.

${ }^{26}$ In Table A9 and Table A10 in the Online Appendix, we present the results of short-term and long-term event studies for abnormal stock and bond returns and provide a more detailed discussion of this analysis. Our event study results also point toward debt overhang and not asymmetric information as the underlying economic reason for why Capital Exercise banks were reluctant to issue equity.
} 
prior to the capital exercise. There is a parallel upward trend in syndicated loan volumes of both groups of banks in the quarters leading up to the capital exercise. Starting in the third quarter of 2011, loan volumes of Capital Exercise banks started to stagnate and then decrease, while loan volumes for banks in the control group kept increasing.

[Figure 6 about here]

Table X presents the results of the difference-in-differences regression Equation (1) in Section II.B for the intensive margin sample. The first column of Table X shows that Capital Exercise banks reduced their exposures in the syndicated loan market by 9 percentage points after the capital exercise compared to banks in the control group. This specification includes fixed effects for banks' home countries, which absorb unobserved shocks affecting all banks headquartered in a given country. The second column of Table $\mathrm{X}$ includes bank-specific control variables to address concerns that differences in bank characteristics are correlated with changes in credit demand, in particular bank size. In this specification, the magnitude of the coefficient increases to 14 percentage points. Credit demand shocks could conceivably also occur outside the bank's home country. For example, Deutsche Bank might reduce its exposures to Spanish firms due to changes in credit demand in Spain. ${ }^{27}$ Similarly, credit demand shocks could occur at the industry level and our results might be driven by Capital Exercise banks having different exposures to different industries than NonCapital Exercise banks. To address these concerns, we include Borrower Country fixed effects in the third column, Industry fixed effects in the fourth column, and Borrower Country $\times$ Industry fixed effects in the fifth column respectively. In the fifth and strongest specification, which rules out that our results are driven by firm-cluster specific demand shocks, we find that Capital Exercise banks reduced their exposures in the syndicated loan market by 17 percentage points compared to banks in the control group. ${ }^{28}$ This large negative effect of higher capital requirements on bank lending is in line with recent findings in the literature (Fraisse, Lé, and Thesmar, 2017).

[Table X about here]

\footnotetext{
${ }^{27}$ In Table A13 in the Online Appendix, we further test whether banks reduced foreign lending significantly more than lending in their home country market, but we do not find evidence for such a "home bias" effect (Giannetti and Laeven, 2012).

${ }^{28}$ Table A12 in the Online Appendix reports the results for credit line and term loan exposures separately. Although capital exercise banks also reduce their term loan exposures, our results are mainly driven by a reduction in credit line exposures. Since credit lines have shorter maturities than term loans, Capital Exercise banks seeking to reduce their risk-weighted assets could achieve this by not rolling over expiring credit lines.
} 
These results are consistent with the bank-level analysis in Section III.A. Capital Exercise banks responded to the increase in capital requirements by reducing outstanding corporate loans. The loan-level part of the paper shows that this reduction can be attributed to a reduction in credit supply and is not driven by demand effects.

\section{Firm-Level Results}

Ultimately, the degree to which a reduction in credit supply from Capital Exercise banks implies real effects at the firm level depends on the extent to which other banks, not subject to higher capital requirements, pick up the slack. To investigate whether such substitution occurs, we divide our sample of firms into "CEB dependent firms" with an above median (65.0\%) dependence on credit supply from Capital Exercise banks as measured by the CEB borrowing share (our treatment group), and "Non-CEB dependent firms" with a below median dependence on credit supply from Capital Exercise banks (our control group pool). Since CEB dependent firms might differ from Non-CEB dependent firms along a number of important characteristics, we employ a difference-indifferences matching methodology analog to the one used in the bank-level part.

Table XI shows the pre-treatment mean values of the matching covariates for CEB-dependent firms, Non-CEB-dependent firms, and matched control group firms as of end of 2010, the year immediately prior to the capital exercise. We use Welch's t-test to test for differences in means between the groups.

\section{[Table XI about here]}

Panel A of Table XI compares the 952 CEB-dependent firms with 1,006 Non-CEB-dependent firms in the unmatched sample. CEB-dependent firms are on average larger than Non-CEB dependent firms in terms of total assets, have a higher ratio of fixed assets to total assets (tangibility) and a higher leverage ratio. These differences between CEB-dependent firms and NonCEB-dependent firms emphasize the necessity of employing a matching procedure. We match four Non-CEB-dependent firms to each CEB-dependent firm based on the Mahalanobis distance of all matching covariates as of end of 2010. This matching procedure renders all differences between CEB-dependent firms and Non-CEB dependent firms insignificant at the $5 \%$ level. 
Figure 7 shows the evolution of total assets, fixed assets, and sales relative to 2010 for unlisted CEB-dependent firms and firms in the matched control group, respectively. Each of the panels shows that the corporate policies of CEB-dependent firms and Non-CEB dependent firms developed similarly up to 2010, the year prior to the capital exercise. Starting in 2011, CEB-dependent firms started to exhibit lower asset-, investment-, and sales growth than firms in the matched control group.

[Figure 7 about here]

We estimate the differences in changes in the logarithms of total assets, fixed assets, and sales from the period before to the period after the capital exercise between CEB-dependent firms and firms in the matched control group. As we expect results to be stronger for firms which are less likely to substitute a reduction in credit supply with other sources of funding, we also split our sample into listed and unlisted firms and report results separately. Panel A of Table XII shows how the 2011 EBA capital exercise affected total assets, investment, and sales of all firms in our sample. Row 1 reports the before-after differences for CEB dependent firms, Row 2 the before-after differences for matched control group firms, and Row 3 the bias-corrected Abadie and Imbens (2002) matching estimator for the average treatment effect on the treated (ATT). The average treatment effect shows that being dependent on funding from Capital Exercise banks had a significant negative effect on asset-, investment-, and sales growth. On average, CEB dependent firms grew by 4 percentage points less, exhibited 6 percentage points less investment growth, and 5 percentage points less sales growth than firms in the matched control group less reliant on funding from Capital Exercise banks.

[Table XII about here]

Panel B and C of Table XII report results separately for the subsample of listed and unlisted firms respectively. As expected, our results are driven by the unlisted firms in our sample which are unable to raise public equity and thus have less alternative sources of funding. We find that unlisted CEB-dependent firms exhibited 6 percentage points less asset growth and 9 percentage points less sales growth than unlisted firms in the matched control group, while we find no significant difference for the sample of listed firms. Thus, our results show that the reduction in credit supply by Capital Exercise banks in response to higher capital requirements yielded significant negative effects for 
firms which obtained a large share of their funding from Capital Exercise banks. We conclude that the EBA capital exercise had negative effects on the real economy.

\section{Conclusion}

We exploit the EBA capital exercise as a quasi-natural experiment to study the effect of higher capital requirements on banks' balance sheet adjustments and the transmission of this effect to the real economy. Using different matching strategies which exploit the selection rule of the EBA capital exercise, we show that Capital Exercise banks increase their core tier 1 ratios more than Non-Capital Exercise banks in response to an increase in capital requirements. This suggests that the capital exercise was an effective policy instrument to improve the capitalization of the largest European banks.

But the capital exercise may also have been a somewhat blunt instrument, because our analysis further shows that banks do not raise their capital ratios by increasing their levels of core tier 1 capital, but by reducing their risk-weighted assets, in particular their credit exposures to corporate and retail clients. Consistent with debt overhang, we find that Capital Exercise banks with more subordinated debt are more likely to shrink assets and retire subordinated debt. As a consequence, we show that firms which are more reliant on credit supplied by Capital Exercise banks exhibit

lower asset-, investment-, and sales growth than firms less reliant on Capital Exercise banks. This suggests that firms were unable to fully substitute the reduction in credit supply by Capital Exercise banks with other sources of financing.

An important policy implication of our paper is that capital requirements which target the regulatory capital ratio have potentially adverse effects on the real economy. As suggested by Hanson, Kashyap, and Stein (2011), targeting the absolute amount of new capital that has to be raised instead of targeting the capital ratio could mitigate this problem, an approach which has been successfully applied in the U.S. stress test conducted in 2009. In an institutional set up in which the recapitalization recommendations are difficult to verify and/or enforce, our paper highlights the risks associated with capital regulation that focuses on capital ratios as the policy target variable, while leaving it to the discretion of banks how to increase their capital ratios. 


\section{REFERENCES}

Abadie, Alberto, and Guido W. Imbens, 2002, Simple and bias-corrected matching estimators for average treatment effects, NBER Technical Working Paper 283, 1-55.

Abadie, Alberto, and Guido W. Imbens, 2011, Bias-corrected matching estimators for average treatment effects, Journal of Business \& Economic Statistics 29, 1-11.

Acharya, Viral V., Tim Eisert, Christian Eufinger, and Christian Hirsch, 2016, Real effects of the sovereign debt crisis in europe: Evidence from syndicated loans, Working Paper.

Acharya, Viral V., Robert Engle, and Diane Pierret, 2014, Testing macroprudential stress tests: The risk of regulatory risk weights, Journal of Monetary Economics 65, 36-53.

Acharya, Viral V., Dirk Schoenmaker, and Sascha Steffen, 2011, How much capital do european banks need? some estimates, VOX CEPRs Policy Portal 22 November 2011.

Admati, Anat R., Peter M. DeMarzo, Martin F. Hellwig, and Paul Pfleiderer, 2017, The leverage ratchet effect, Journal of Finance forthcoming.

Aiyar, Shekhar, Charles W. Calomiris, John Hooley, Yevgeniya Korniyenko, and Tomasz Wieladek, 2014, The international transmission of bank capital requirements: Evidence from the UK, Journal of Financial Economics 113, 368-382.

Almeida, Heitor, Murillo Campello, Bruno Laranjeira, and Scott Weisbenner, 2011, Corporate debt maturity and the real effects of the 2007 credit crisis, Critical Finance Review 1, 3-58.

Bahaj, Saleem, and Frederic Malherbe, 2017, A positive analysis of bank behaviour under capital requirements, Working Paper.

Behn, Markus, Rainer Haselmann, and Vikrant Vig, 2016, The limits of model-based regulation, ECB Working Paper Series 1928.

Berg, Tobias, Anthony Saunders, and Sascha Steffen, 2016, The total cost of corporate borrowing in the loan market: Don’t ignore the fees, Journal of Finance 71, 1357-1392. 
Berger, Allen N., and Gregory F. Udell, 1994, Did risk-based capital allocate bank credit and cause a "credit crunch" in the United States?, Journal of Money, Credit and Banking 26, 585-628.

Bertrand, Marianne, Esther Duflo, and Sendhil Mullainathan, 2004, How much should we trust difference-in-differences estimates?, The Quarterly Journal of Economics 119, 249-275.

Bessembinder, Hendrik, Kathleen M. Kahle, William F. Maxwell, and Danielle Xu, 2009, Measuring abnormal bond performance, Review of Financial Studies 22, 4219-4258.

BIS, 2005, International convergence of capital measurement and capital standards: A revised framework November 2005.

Calonico, Sebastian, Matias D. Cattaneo, and Rocio Titiunik, 2014, Robust nonparametric confidence intervals for regression-discontinuity designs, Econometrica 82, 2295-2326.

Campello, Murillo, and Erasmo Giambona, 2013, Real assets and capital structure, Journal of Financial Quantitative Analysis 48, 1333-1370.

Campello, Murillo, and Mauricio Larrain, 2016, Enlarging the contracting space: Collateral menus, access to credit, and economic activity, Review of Financial Studies 29, 349-383.

Cattaneo, Matias D., Michael Jansson, and Xinwei Ma, 2017, Manipulation testing based on density discontinuity, Working Paper.

Célérier, Claire, Thomas Kick, and Steven Ongena, 2016, Changes in the cost of bank equity and the supply of bank credit, Working Paper.

De Haas, Ralph, and Neeltje Van Horen, 2012, Running for the exit? International bank lending during a financial crisis, Review of Financial Studies 26, 244-285.

De Marco, Filippo, and Tomasz Wieladek, 2015, The real effects of capital requirements and monetary policy: Evidence from the United Kingdom, Bank of England Staff Working Paper 573.

EBA, 2011a, 2011 EU-wide stress test: Methodological note.

EBA, 2011b, EBA recommendation on the creation and supervisory oversight of temporary capital buffers to restore market confidence (EBA/REC/2011/1) on december 8, 2011. 
EBA, 2011c, Questions and answers, 26th October, 2011.

Eberhart, Allan C., and Akhtar Siddique, 2002, The long-term performance of corporate bonds (and stocks) following seasoned equity offerings, Review of Financial Studies 15, 1385-1406.

Fraisse, Henri, Mathias Lé, and David Thesmar, 2017, The real effects of bank capital requirements, ESRB Working Paper Series 47.

Giannetti, Mariassunta, and Luc Laeven, 2012, The flight home effect: Evidence from the syndicated loan market during financial crises, Journal of Financial Economics 104, 23-43.

Greenlaw, David, Anil K. Kashyap, Kermit Schoenholtz, and Hyun Song Shin, 2012, Stressed out: Macroprudential principles for stress testing, Chicago Booth Working Paper 12-08, 1-51.

Gropp, Reint, and Florian Heider, 2010, The determinants of bank capital structure, Review of Finance 14, 587-622.

Halstrick, Philipp, and Andreas Framke, 2011, Exclusive: Europe hits banks with tougher capital test, Reuters, October 11, 2011.

Hanson, Samuel G., Anil K. Kashyap, and Jeremy C. Stein, 2011, A macroprudential approach to financial regulation, Journal of Economic Perspectives 25, 3-28.

Hirtle, Beverly, Til Schuermann, and Kevin Stiroh, 2009, Macroprudential supervision of financial institutions: Lessons from the SCAP, Federal Reserve Bank of New York Staff Reports 409, 1-15.

Imbens, Guido W., 2014, Matching methods in practice: Three examples, NBER Working Paper Series 19959.

Jenkins, Patrick, Ralph Atkins, and Peter Spiegel, 2011, Europe's banks face 9\% capital rule, Financial Times, October 11, 2011.

Jensen, Thais Lærkholm, 2015, The real effects of higher capital requirements: Evidence from Danish firm-level data, Working Paper.

Jimenéz, Gabriel, Steven Ongena, José-Luis Peydró, and Jesús Saurina, 2017, Macroprudential policy, countercyclical bank capital buffers and credit supply: Evidence from the spanish dynamic provisioning experiments, Journal of Political Economy 125, 2126-2177. 
Jordà, Òscar, 2005, Estimation and inference of impulse responses by local projections, American Economic Review 95, 161-182.

Kahle, Kathleen M., and René M. Stulz, 2013, Access to capital, investment, and the financial crisis, Journal of Financial Economics 110, 280-299.

Kashyap, Anil K., Jeremy C. Stein, and Samuel Hanson, 2010, An analysis of the impact of "substantially heightened" capital requirements on large financial institutions, Working Paper.

Khwaja, Asim Ijaz, and Atif Mian, 2008, Tracing the impact of bank liquidity shocks: Evidence from an emerging market, American Economic Review 98, 1413-1442.

Kisin, Roni, and Asaf Manela, 2016, The shadow cost of bank capital requirements, Review of Financial Studies 29, 1780-1820.

Lubberink, Martien, 2014, A primer on regulatory bank capital adjustments, Working Paper.

Mésonnier, Jean-Stéphane, and Allen Monks, 2015, Did the EBA capital exercise cause a credit crunch in the Euro area?, International Journal of Central Banking June 2015, 75-117.

Peek, Joe, and Eric S. Rosengren, 1997, The international transmission of financial shocks: The case of Japan, American Economic Review 87, 495-505.

Popov, Alexander, and Neeltje Van Horen, 2015, Exporting sovereign stress: Evidence from syndicated bank lending during the euro area sovereign debt crisis, Review of Finance 19, 1825-1866.

Vallée, Boris, 2016, Contingent capital trigger effects: Evidence from liability management exercises, Working Paper. 


\section{Appendix A: Figures}

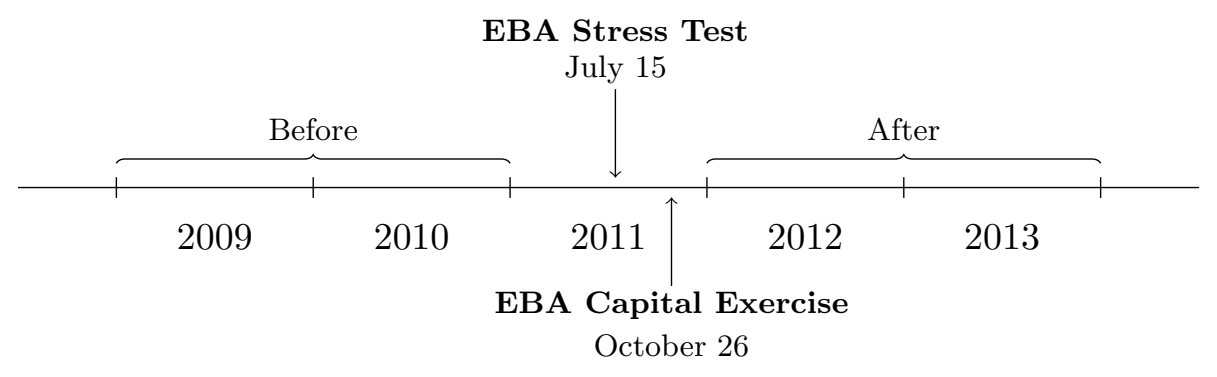

Figure 1. 2011 EBA Capital Exercise Timeline. This figure shows the timeline of the 2011 EBA capital exercise including the definition of the before and after period used in the paper. 


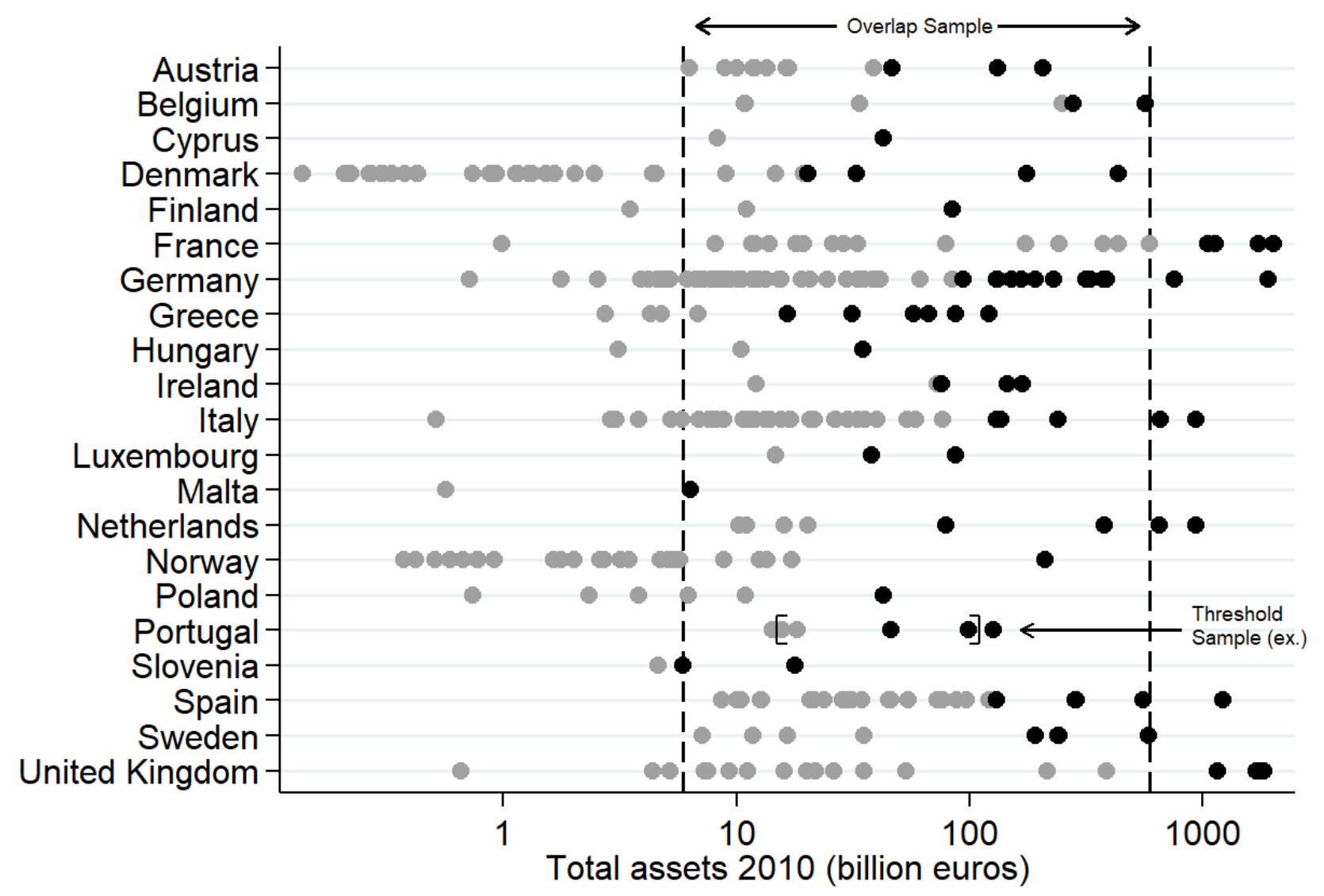

- Capital Exercise Banks Non-Capital Exercise Banks

Figure 2. Bank Size Distribution by Country. This figure shows the bank size distribution (total assets as of end of 2010) of Capital Exercise banks and Non-Capital Exercise banks by country. The graph includes all ultimate parent banks headquartered in EBA supervised countries included in the SNL database. The figure also illustrates the construction of the overlap sample and the threshold sample. The overlap sample includes all banks larger than the smallest Capital Exercise bank (left vertical line) and smaller than the largest Non-Capital Exercise bank (right vertical line). The threshold sample includes the two smallest Capital Exercise banks and the two largest Non-Capital Exercise banks in each country (e.g. in Portugal). 
(a) Full Sample

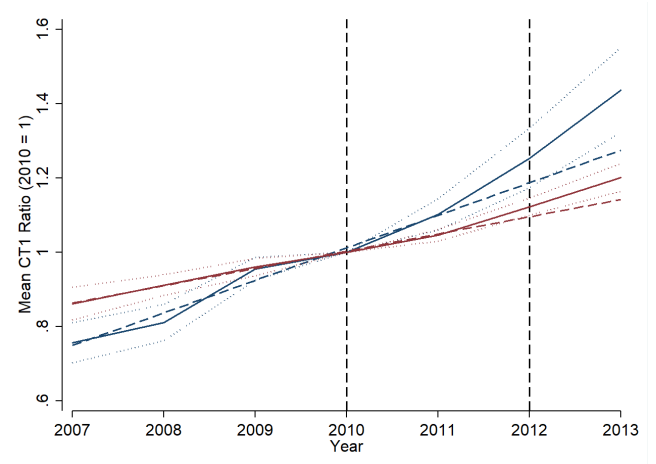

(c) Within Country

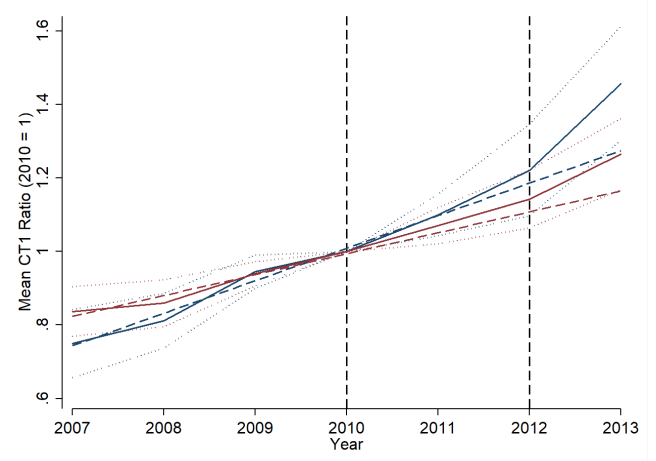

(b) Overlap

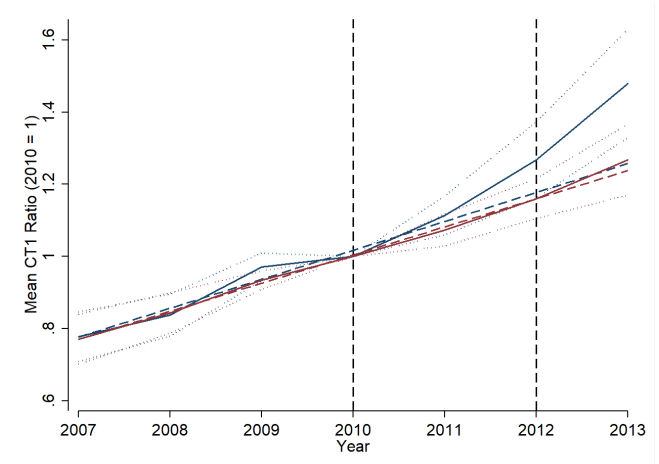

(d) Within Region

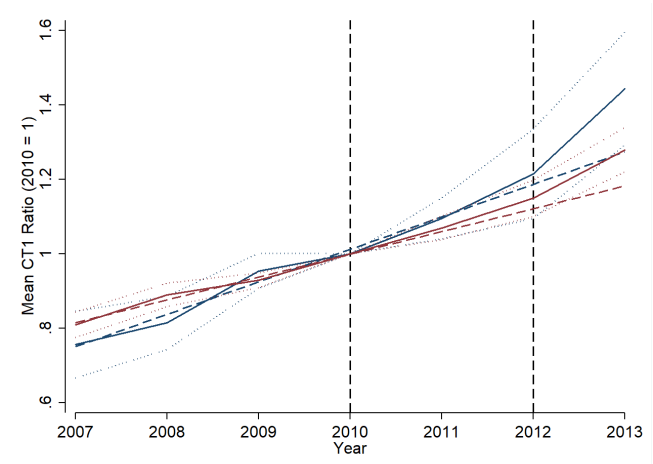

Figure 3. Core Tier 1 Ratios Over Time. This figure shows the evolution of the mean of core tier 1 (CT1) ratios over time for both 48 Capital Exercise banks in the treatment group (solid blue line) and 76 banks in the matched control group (solid red line) based on the four matching strategies. The two dashed vertical lines in each panel mark 2010 and 2012, the years immediately before and after the capital exercise. The dashed red and blue lines indicate the extrapolated pre-treatment trends and the dotted lines indicated the $95 \%$ confidence intervals. 
(a) Full Sample

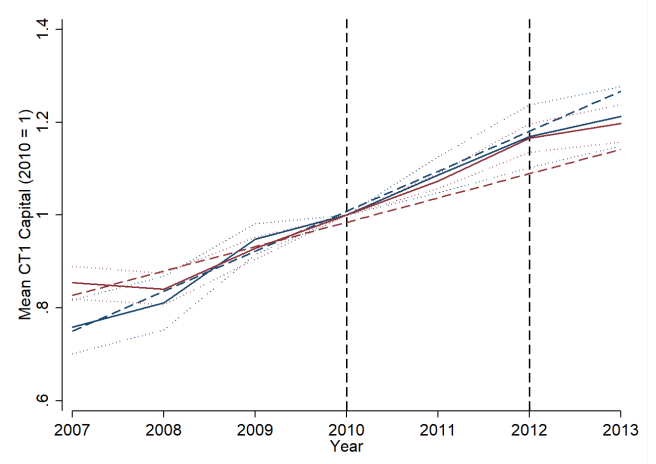

(c) Within Country

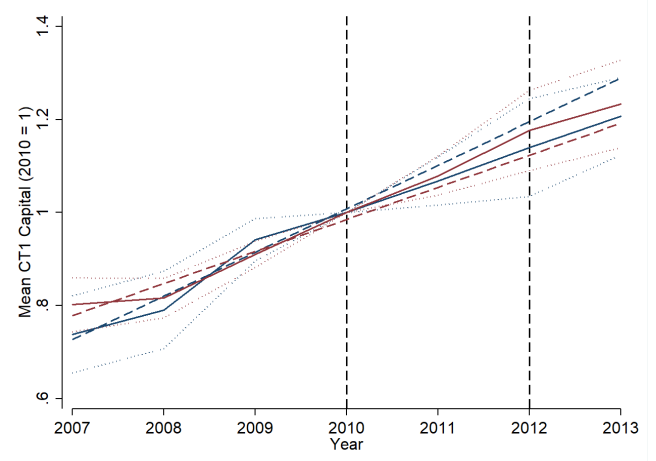

(b) Overlap

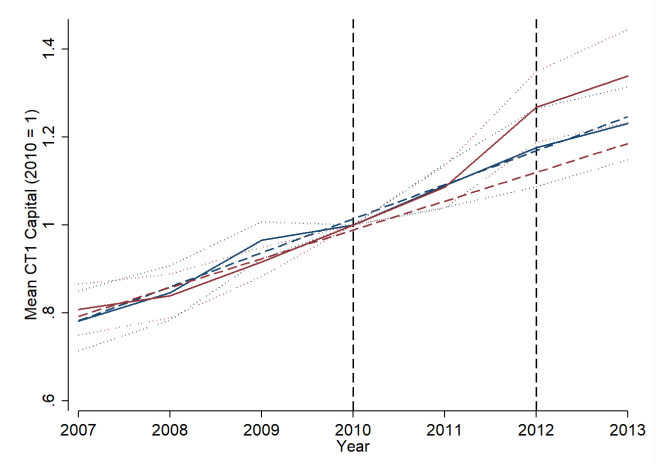

(d) Within Region

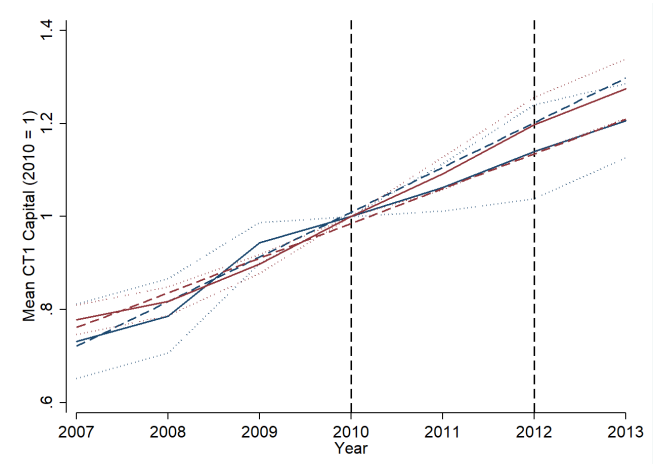

Figure 4. Core Tier 1 Capital Over Time. This figure shows the evolution of the mean of core tier 1 (CT1) capital over time for both 48 Capital Exercise banks in the treatment group (solid blue line) and 76 banks in the matched control group (solid red line) based on the four matching strategies. The two dashed vertical lines in each panel mark 2010 and 2012, the years immediately before and after the capital exercise. The dashed red and blue lines indicate the extrapolated pre-treatment trends and the dotted lines indicated the $95 \%$ confidence intervals. 
(a) Full Sample

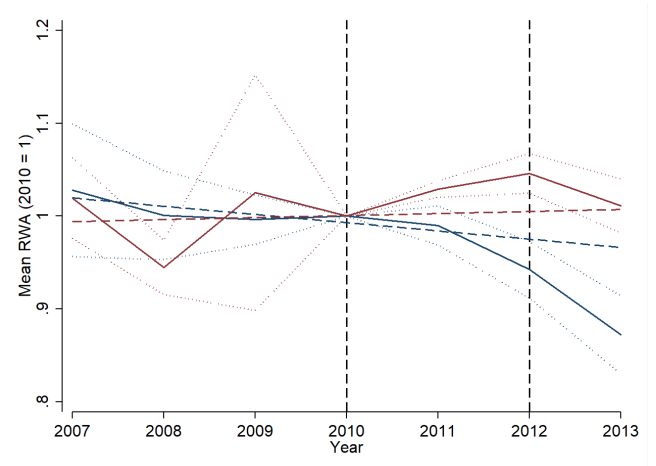

(c) Within Country

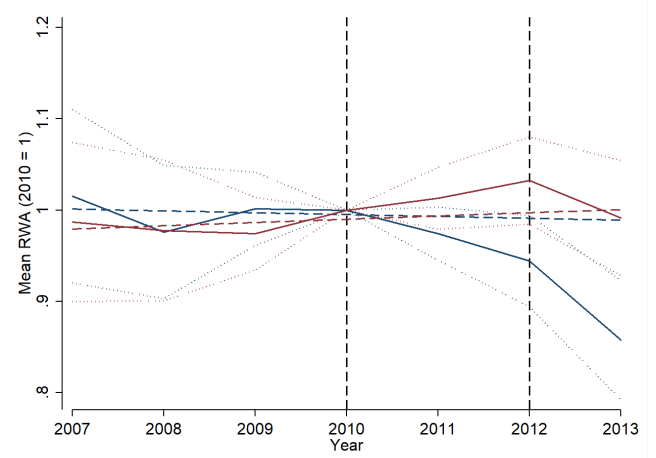

(b) Overlap

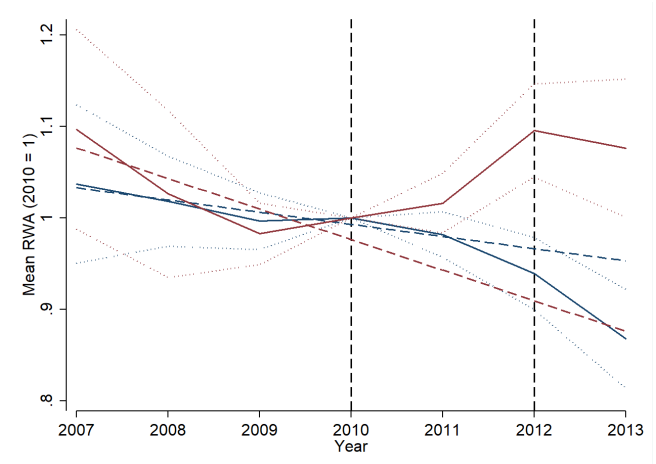

(d) Within Region

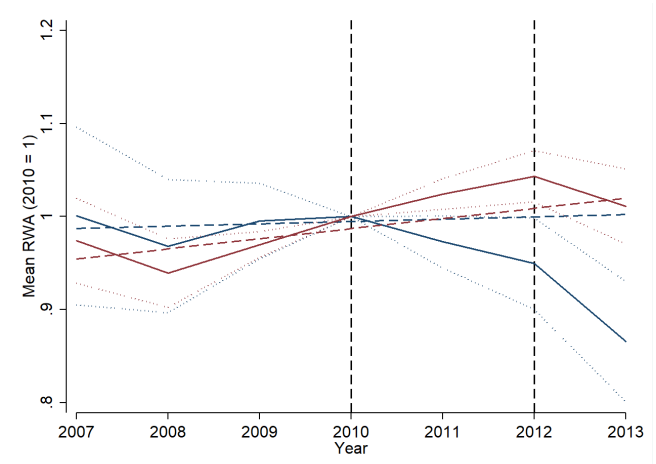

Figure 5. Risk-Weighted Assets Over Time. This figure shows the evolution of the mean of risk-weighted assets (RWA) over time for both 48 Capital Exercise banks in the treatment group (solid blue line) and 76 banks in the matched control group (solid red line) based on the four matching strategies. The two dashed vertical lines in each panel mark 2010 and 2012, the years immediately before and after the capital exercise. The dashed red and blue lines indicate the extrapolated pre-treatment trends and the dotted lines indicated the $95 \%$ confidence intervals. 


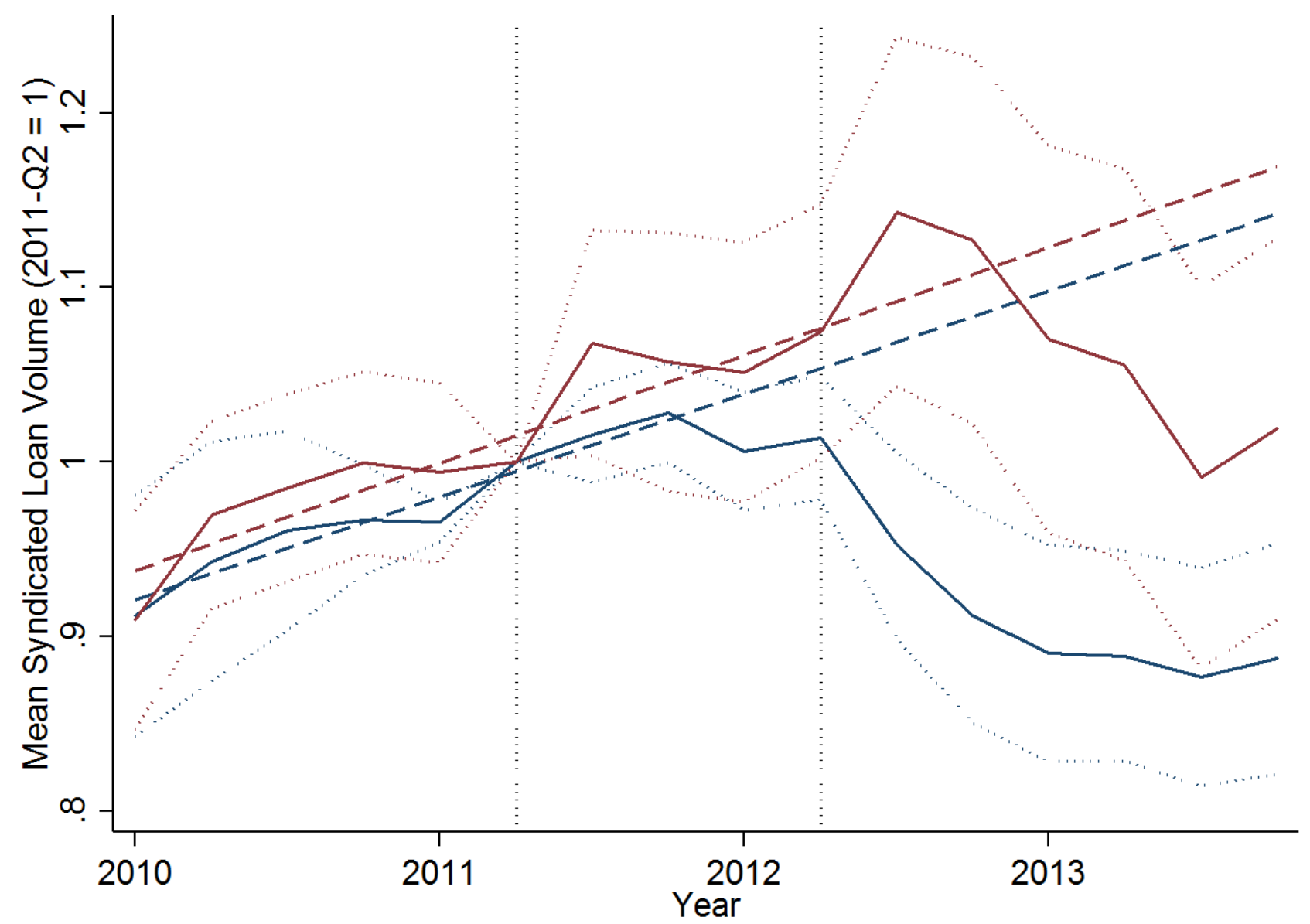

Figure 6. Syndicated Lending Over Time. This figure shows the outstanding syndicated loan volume of Capital Exercise banks (solid blue line) and Non-Capital Exercise banks (solid red line) over the period 2010Q1-2013Q4, normalized to one in 2011Q2. The two dashed vertical lines in each panel mark 2011Q2 and 2012Q2, the years immediately before and after the capital exercise. The dashed red and blue lines indicate the extrapolated pre-treatment trends and the dotted lines indicated the $95 \%$ confidence intervals. 
(a) Firm Total Assets over Time

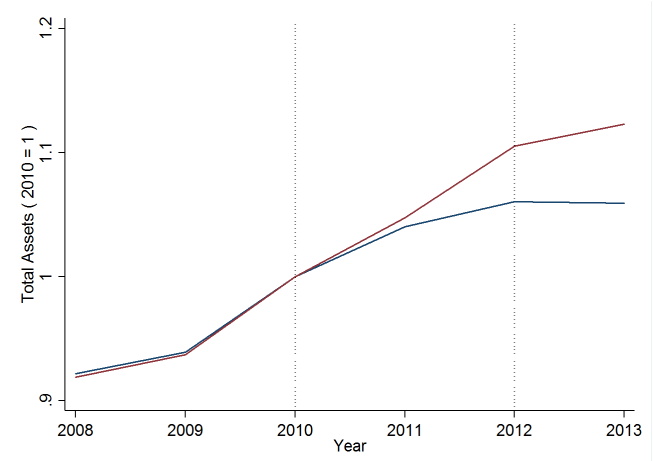

(b) Firm Fixed Assets over Time

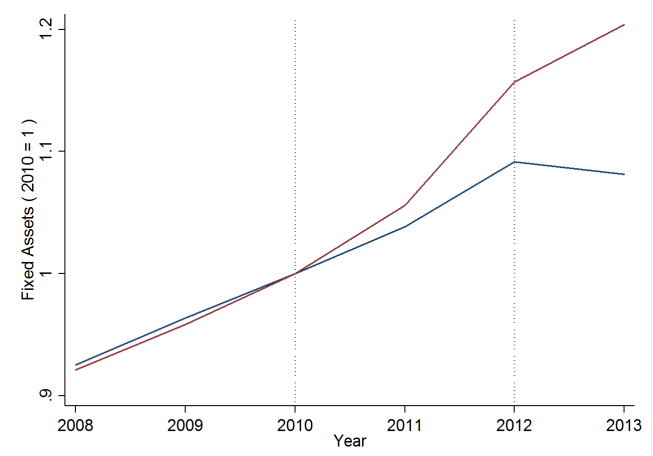

(c) Firm Sales over Time

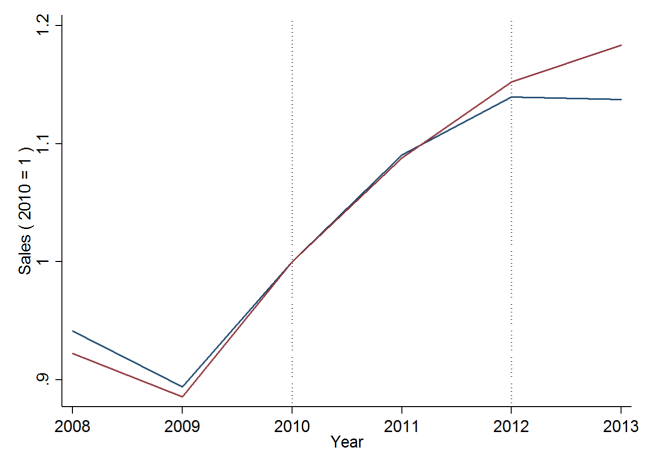

Figure 7. Firm-Level Outcomes Over Time. This figure shows the evolution of the mean total assets (Panel A), mean fixed assets (Panel B), and mean sales (Panel C) for both 681 unlisted CEB-dependent firms (solid blue line) and 793 unlisted Non-CEB dependent firms (solid red line) firms in the matched control group, normalized to the value of for the year 2010. The two dashed vertical lines mark 2010 and 2012, the years immediately before and after the capital exercise. 


\section{Appendix B: Tables}

\section{Table I \\ Matching Strategies}

This table displays the four matching strategies employed in the paper. The full sample includes 48 Capital Exercise banks and 144 Non-Capital Exercise banks. The overlap sample includes all banks larger than the smallest Capital Exercise bank and smaller than the largest Non-Capital Exercise bank. The threshold sample includes the two smallest Capital Exercise banks and the two largest Non-Capital Exercise banks per country. The number of matches refers to the number of control group banks matched to each Capital Exercise bank. The matching covariate Region takes the value of 1 if the bank is headquartered in Greece, Ireland, Italy, Portugal or Spain (GIIPS countries), and 0 otherwise.

\begin{tabular}{lcccc}
\hline Matching Strategy & Full Sample & Overlap & $\begin{array}{c}\text { Within } \\
\text { Country }\end{array}$ & $\begin{array}{c}\text { Within } \\
\text { Region }\end{array}$ \\
\hline Sample Used & Full Sample & Overlap & Threshold & Threshold \\
Number of Matches & $1: 4$ & $1: 1$ & $1: 2$ & $1: 4$ \\
Matching covariates & & & & \\
Total Assets & & & $\sqrt{ }$ & $\sqrt{ }$ \\
CT1 Capital Ratio & $\sqrt{ }$ & $\sqrt{ }$ & $\sqrt{ }$ \\
Total Deposits / Total Assets & $\sqrt{ }$ & & $\sqrt{ }$ & $\sqrt{ }$ \\
Customer Loans / Total Assets & $\sqrt{ }$ & & $\sqrt{ }$ & $\sqrt{ }$ \\
Net Int. Inc. / Op. Rev. & $\sqrt{ }$ & & \\
Net Income / Total Assets & $\sqrt{ }$ & & $\sqrt{ }$ \\
Country & & & $\sqrt{ }$ \\
Region & & & \\
\end{tabular}




\section{Table II \\ Summary Statistics}

This table provides the summary statistics for all the dependent variables used in the paper. Panel A provides the summary statistics of the depended variables used in the bank-level part for the full sample (48 Capital Exercise banks and 144 Non-Capital Exercise banks), Panel B the summary statistics of the dependent variables used in the loan-level part and Panel $\mathrm{C}$ the summary statistics of the dependent variable used in the firm-level part.

Variable

Mean

Median

$\mathrm{SD}$

Panel A: Variables Used in the Bank-Level Analysis

$\begin{array}{lccc}\Delta \text { CT1 Ratio } & 1.82 & 1.95 & 2.60 \\ \Delta \text { Log CT1 Capital } & 0.19 & 0.19 & 0.23 \\ \Delta \text { Log Tier 1 Common Equity } & 0.17 & 0.18 & 0.26 \\ \Delta \text { Log Retained Earnings } & 0.11 & 0.18 & 0.62 \\ \Delta \text { Log Share Capital \& Premium } & 0.23 & 0.10 & 0.48 \\ \Delta \text { (Regulatory Adjustments / CT1 } & -0.01 & 0.00 & 0.34 \\ \text { Capital) } & & & \\ \Delta \text { Log RWA } & 0.02 & 0.01 & 0.23 \\ \Delta \text { Log Credit RWA } & 0.00 & -0.01 & 0.23 \\ \Delta \text { Log Corporate Exposures } & -0.16 & -0.10 & 0.53 \\ \Delta \text { Log Retail Exposures } & -0.04 & -0.02 & 0.37 \\ \quad \Delta \text { Log Sovereign Exposures } & 0.02 & 0.08 & 1.33 \\ \quad \Delta \text { Log Other Exposures } & 0.38 & 0.35 & 1.01 \\ \Delta \text { Log Market RWA } & -0.16 & 0.03 & 1.18 \\ \Delta \text { Log Operational RWA } & 0.12 & 0.09 & 0.28 \\ \Delta \text { (RWA / Total Assets) } & -4.34 & -2.74 & 8.66 \\ \Delta \text { (Loan Loss Reserves / Customer Loans) } & 1.42 & 0.41 & 2.76 \\ \Delta \text { Log Total Assets } & 0.11 & 0.09 & 0.21 \\ \Delta \text { Log Customer Loans } & 0.10 & 0.09 & 0.26 \\ \Delta \text { Log Total Securities } & 0.16 & 0.13 & 0.53\end{array}$

Panel B: Variables Used in the Loan-Level Analysis

$\Delta$ Log Loan Exposure

$-0.02$

0.00

0.68

Panel C: Variables Used in the Firm-Level Analysis

$\Delta \log$ Total Assets

$\begin{array}{lll}0.10 & 0.07 & 0.34 \\ 0.11 & 0.05 & 0.43 \\ 0.14 & 0.13 & 0.49\end{array}$

$\Delta$ Log Sales

0.14

0.49 
Table III

Pre-Treatment Characteristics of Banks

This table provides pre-treatment summary statistics on Capital Exercise banks, Non-Capital Exercise banks and control group banks (mean comparison). Panel A compares the mean values of the 48 Capital Exercise banks and 144 Non-Capital Exercise banks in the unmatched sample. Panels B to E compare Capital Exercise banks to the sample of matched control group banks using the full sample matching, overlap matching, within country matching and within region matching strategies respectively. Table I lists the matching covariates used for each matching strategy. The paper tests for differences in means using Welch's t-test. *, **, and *** indicate statistical significance at the $10 \%, 5 \%$, and $1 \%$ level respectively.

$\begin{array}{ccccccc} & \text { Total } & \text { CT1 } & \text { Deposits } / & \text { Loans / } & \text { NII / } & \text { Net Inc./ } \\ \text { \# Banks } & \text { Assets } & \text { Ratio } & \text { TA } & \text { TA } & \text { Op. Rev. } & \text { TA }\end{array}$

Panel A: Unmatched Sample

EBA Banks

Non-EBA Banks

48

144

$\Delta$

Panel B: Full Sample Matching

EBA Banks

48

Matched Group Group

$\Delta$

76

Panel C: Overlap Matching

EBA Banks

36

Matched Group Group

$\Delta$

16

Panel D: Within Country Matching EBA Banks

Matched Group Group

25
25

$\Delta$

Panel E: Within Region Matching

EBA Banks

26

26
Matched Group Group

454.31
24.43
$429.87^{* * *}$

9.86
11.41
$-1.55^{* *}$

40.93
55.54

454.31

107.14

$347.17^{* * *}$

9.86

10.30

$-0.44$
40.93
47.89
$-6.95^{* * *}$

161.32
156.10
5.22

9.98
10.95
-0.96

41.97
53.80

$-11.83^{* *}$

\subsection{8}

80.92

$239.96^{* * *}$

9.96

10.80

$-0.84^{*}$

43.51

43.21

0.31

310.18

180.49

229.69*

$\begin{array}{cc}10.01 & 44.85 \\ 9.95 & 47.63 \\ 0.07 & -2.77\end{array}$

56.73
66.62

$-9.89^{* * *}$

60.42

$$
67.69
$$

$-7.27^{* *}$

0.39

0.41

$-0.02$

$\Delta$
56.73

64.80

$-8.07^{* * *}$

60.42

64.62

$-4.19^{* * *}$

0.39

0.41

$-0.02$

59.78

57.06

2.72

61.95

61.95
71.89

0.40

0.38

$-9.94$

0.02
59.08

61.72

$-2.64$

58.80

71.22

$-12.42^{*}$

0.40

0.42
-0.02

$\begin{array}{ccc}59.77 & 58.99 & 0.45 \\ 64.12 & 59.39 & 0.50 \\ -4.35^{*} & -0.40 & -0.04\end{array}$




\section{Table IV \\ Pre-Treatment Trends in Core Tier 1 Ratios}

This table presents the mean change in core tier 1 ratios, the logarithms of core tier 1 capital, and the logarithms of risk-weighted assets for Capital Exercise banks and control group banks between 2010 and 2009, 2008 and 2007 respectively. The paper tests for differences in means using Welch's t-test. ${ }^{*}, * *$, and $* * *$ indicate statistical significance at the $10 \%, 5 \%$, and $1 \%$ level respectively.

\begin{tabular}{|c|c|c|c|c|c|c|}
\hline \multirow{3}{*}{ Variable } & \multicolumn{3}{|c|}{ Panel A: Full Sample } & \multicolumn{3}{|c|}{ Panel B: Overlap } \\
\hline & \multicolumn{3}{|c|}{ Matched } & \multicolumn{3}{|c|}{ Matched } \\
\hline & Treatmen & Control & $\Delta$ & Treatment & Control & $\Delta$ \\
\hline$\Delta$ CT1 Ratio (2010-2009) & 0.53 & 0.56 & -0.03 & 0.40 & 0.70 & -0.30 \\
\hline$\Delta$ CT1 Ratio (2010-2008) & 1.97 & 1.04 & $0.93^{* * *}$ & 1.76 & 1.73 & 0.02 \\
\hline$\Delta$ CT1 Ratio (2010-2007) & 2.41 & 1.71 & $0.70^{*}$ & 2.22 & 2.65 & -0.43 \\
\hline$\Delta$ Log CT1 Capital (2010-2009) & 0.06 & 0.09 & $-0.03^{*}$ & 0.04 & 0.09 & $-0.05^{*}$ \\
\hline$\Delta$ Log CT1 Capital (2010-2008) & 0.25 & 0.20 & 0.04 & 0.19 & 0.19 & 0.00 \\
\hline$\Delta$ Log CT1 Capital (2010-2007) & 0.31 & 0.20 & $0.11^{* * *}$ & 0.28 & 0.24 & 0.04 \\
\hline$\Delta$ Log RWA (2010-2009) & 0.01 & 0.03 & -0.02 & 0.01 & 0.02 & -0.01 \\
\hline$\Delta \log$ RWA (2010-2008) & 0.02 & 0.09 & $-0.07^{* *}$ & -0.01 & 0.00 & -0.01 \\
\hline \multirow[t]{2}{*}{$\Delta$ Log RWA (2010-2007) } & 0.00 & 0.02 & -0.02 & -0.01 & -0.05 & 0.05 \\
\hline & \multicolumn{3}{|c|}{ Panel C: Within Country } & \multicolumn{3}{|c|}{ Panel D: Within Region } \\
\hline \multirow[t]{2}{*}{ Variable } & \multicolumn{3}{|c|}{ Matched } & \multicolumn{3}{|c|}{ Matched } \\
\hline & Treatmen & Control & $\Delta$ & Treatment & Control & $\Delta$ \\
\hline$\Delta$ CT1 Ratio (2010-2009) & 0.66 & 0.68 & -0.01 & 0.56 & 0.75 & -0.19 \\
\hline$\Delta$ CT1 Ratio (2010-2008) & 2.04 & 1.73 & 0.31 & 2.02 & 1.11 & $0.91^{*}$ \\
\hline$\Delta$ CT1 Ratio (2010-2007) & 2.66 & 1.97 & 0.69 & 2.60 & 1.85 & 0.74 \\
\hline$\Delta$ Log CT1 Capital (2010-2009) & 0.07 & 0.10 & -0.03 & 0.06 & 0.12 & $-0.05^{* *}$ \\
\hline$\Delta$ Log CT1 Capital (2010-2008) & 0.28 & 0.23 & 0.05 & 0.28 & 0.22 & 0.07 \\
\hline$\Delta$ Log CT1 Capital (2010-2007) & 0.34 & 0.27 & 0.07 & 0.35 & 0.28 & 0.07 \\
\hline$\Delta$ Log RWA (2010-2009) & 0.00 & 0.03 & -0.03 & 0.01 & 0.04 & -0.02 \\
\hline$\Delta$ Log RWA (2010-2008) & 0.05 & 0.04 & 0.01 & 0.05 & 0.08 & -0.03 \\
\hline$\Delta$ Log RWA (2010-2007) & 0.01 & 0.05 & -0.04 & 0.03 & 0.06 & -0.03 \\
\hline
\end{tabular}




\section{Table V \\ Adjustment of Core Tier 1 Ratios}

This table presents the estimates of the change in core tier 1 ratios and its components. The dependent variables are the change in the core tier 1 (CT1) ratio, the logarithm of core tier 1 (CT1) capital, and the logarithm of the risk-weighted assets (RWA). In each panel, the first row contains the difference in the outcome variable for Capital Exercise banks (CEB) between the before (2009 and 2010) and the after (2012 and 2013) period, and the second row the difference in the outcome variable for matched control group (Control) banks over the same period. The paper tests for differences-in-means using Welch's two-sample t-test. The third row contains the estimate for the average treatment effect on the treated (ATT) based on the bias-corrected Abadie and Imbens (2002) matching estimator. Panel A presents the results for the full sample matching strategy, Panel B the results for the overlap matching strategy, Panel C presents the results for the within country matching strategy, and Panel D the results for the within region matching strategy. *, **, and $* * *$ indicate statistical significance at the $10 \%, 5 \%$, and $1 \%$ level respectively.

Dependent Variable

Panel A: Full Sample Matching

CEB: After - Before

Control: After - Before

Bias-Corrected ATT

Number of Observations

Panel B: Overlap Matching

CEB: After - Before

Control: After - Before

Bias-Corrected ATT

Number of Observations

Panel C: Within Country Matching

CEB: After - Before

Control: After - Before

Bias-Corrected ATT

Number of Observations
$\Delta \mathrm{CT} 1$ Ratio

$\Delta$ Log CT1 Capital

$\Delta \log$ RWA

$0.19^{* * *}$
$0.19^{* * *}$
0.02
48

48

$0.18^{* * *}$
$0.29^{* * *}$
-0.10
36

36
$3.29^{* * *}$

$2.34^{* * *}$

$1.19^{* *}$

25
$0.17^{* * *}$
$0.21^{* * *}$
$-0.07^{*}$
25

$$
\begin{gathered}
-0.10^{* * *} \\
0.03 \\
-0.16^{* * *} \\
48
\end{gathered}
$$

Panel D: Within Region Matching

CEB: After - Before

Control: After - Before

Bias-Corrected ATT

Number of Observations
$3.16^{* * *}$
$2.15^{* * *}$
$1.01^{* *}$
26

$0.17^{* * *}$
$0.25^{* * *}$
-0.06
26

$-0.11^{* * *}$

$0.04^{* * *}$

$-0.13^{* *}$

26 


\section{Table VI \\ Adjustment of Core Tier 1 Capital Components}

This table presents the estimates of the change in the components of core tier 1 capital. The dependent variables are the change in the logarithm of core tier 1 common equity, the logarithm of retained earnings, the logarithm of share capital and share premium, and the ratio of regulatory adjustments over core tier 1 capital. In each panel, the first row contains the difference in the outcome variable for Capital Exercise banks (CEB) between the before (2009 and 2010) and the after (2012 and 2013) period, and the second row the difference in the outcome variable for matched control group (Control) banks over the same period. The paper tests for differences-in-means using Welch's two-sample t-test. The third row contains the estimate for the average treatment effect on the treated (ATT) based on the bias-corrected Abadie and Imbens (2002) matching estimator. Panel A presents the results for the full sample matching strategy, and Panel B the results for the overlap matching strategy. * **, and *** indicate statistical significance at the $10 \%, 5 \%$, and $1 \%$ level respectively.

\begin{tabular}{lcccc}
\hline Dependent Variable & $\begin{array}{c}\text { Log Tier } 1 \\
\text { Common } \\
\text { Equity }\end{array}$ & $\begin{array}{c}\Delta \text { Log } \\
\text { Retained } \\
\text { Earnings }\end{array}$ & $\begin{array}{c}\Delta \text { Log Share } \\
\text { Capital \& } \\
\text { Premium }\end{array}$ & $\begin{array}{c}\Delta \text { (Regulatory } \\
\text { Adjustments / } \\
\text { CT1 Capital) }\end{array}$ \\
Panel A: Full Sample Matching & & & \\
CEB: After - Before & $0.12^{* * *}$ & 0.04 & 0.16 & $-0.09^{* *}$ \\
Control: After - Before & $0.19^{* * *}$ & $0.14^{* * *}$ & $0.24^{* * *}$ & 0.01 \\
Bias-Corrected ATT & -0.08 & -0.11 & -0.06 & $-0.11^{* *}$ \\
Number of Observations & 48 & 48 & 48 & 48 \\
& & & & \\
Panel B: Overlap Matching & & & & -0.06 \\
CEB: After - Before & $0.13^{* * *}$ & 0.05 & 0.16 & 0.00 \\
Control: After - Before & $0.29^{* * *}$ & $0.14^{* * *}$ & $0.43^{* * *}$ & -0.06 \\
Bias-Corrected ATT & $-0.16^{*}$ & -0.09 & -0.26 & 36 \\
Number of Observations & 36 & 36 & 36 & \\
& & & & \\
\hline
\end{tabular}




\section{Table VII}

\section{Adjustment of Risk-Weighted Assets Components}

This table presents the estimates of the change in the components of risk-weighted assets. The dependent variables are the change in the logarithm of credit risk-weighted assets (cRWA), consisting of credit risk-weighted assets for corporate exposures, retail exposures, and sovereign exposures, and the change in the logarithms of market risk-weighted assets (mRWA) and operational risk-weighted assets (oRWA). In each panel, the first row contains the difference in the outcome variable for Capital Exercise banks (CEB) between the before (2009 and 2010) and the after (2012 and 2013) period, and the second row the difference in the outcome variable for matched control group (Control) banks over the same period. The paper tests for differences-in-means using Welch's two-sample t-test. The third row contains the estimate for the average treatment effect on the treated (ATT) based on the bias-corrected Abadie and Imbens (2002) matching estimator. Panel A presents the results for the full sample matching strategy, and Panel B the results for the overlap matching strategy. ${ }^{*}, * *$, and $* * *$ indicate statistical significance at the $10 \%, 5 \%$, and $1 \%$ level respectively.

Dependent Variable

$$
\Delta \log \mathrm{cRWA}
$$

$\triangle \log$ CRWA

Panel A: Full Sample Matching

CEB: After - Before

Control: After - Before

Bias-Corrected ATT

Panel B: Overlap Matching
Number of Observations

$$
\begin{array}{cc}
-0.13^{* * *} & -0.23^{* *} \\
-0.03^{* * *} & -0.02 \\
-0.20^{* * *} & -0.24^{* *} \\
48 & 47
\end{array}
$$

$$
\begin{array}{cc}
-0.13^{* * *} & -0.24^{* * *} \\
0.06^{*} & 0.38^{* * *} \\
-0.19^{* *} & -0.63^{* *} \\
36 & 35
\end{array}
$$

Bias-Corrected ATT

Number of Observations

$$
\begin{gathered}
-0.10^{*} \\
0.10^{* * *} \\
-0.34^{* * *} \\
47
\end{gathered}
$$$$
\begin{gathered}
-0.04 \\
-0.03 \\
0.88^{*} \\
40
\end{gathered}
$$$$
\begin{gathered}
-0.08 \\
-0.29^{* * *} \\
0.02 \\
46
\end{gathered}
$$

$0.08^{*}$ $0.09^{* * *}$

0.04

47

$\Delta \log$ mRWA $\quad \Delta \log$ oRWA 


\section{Table VIII}

\section{Risk Reduction and Asset Shrinking}

This table presents the estimates of the change of outcome variables associated with risk reduction and asset shrinking behavior. The dependent variables are the change in the ratio of risk-weighted assets over total assets (RWA/TA), the ratio of loan loss reserves over customer loans (LLR/Cust.Loans), and the logarithms of total assets (TA), customer loans, and total securities. In each panel, the first row contains the difference in the outcome variable for Capital Exercise banks (CEB) between the before (2009 and 2010$)$ and the after (2012 and 2013) period, and the second row the difference in the outcome variable for matched control group (Control) banks over the same period. The paper tests for differences-in-means using Welch's two-sample t-test. The third row contains the estimate for the average treatment effect on the treated (ATT) based on the bias-corrected Abadie and Imbens (2002) matching estimator. Panel A presents the results for the full sample matching strategy, and Panel B the results for the overlap matching strategy. *, **, and *** indicate statistical significance at the $10 \%, 5 \%$, and $1 \%$ level respectively.

Risk Reduction

Dependent Variable

Risk Reduction

$$
\Delta(\mathrm{RWA} / \mathrm{TA}) \quad \Delta\left(\begin{array}{c}
\mathrm{LLR} / \mathrm{Cust} . \\
\text { Loans })
\end{array}\right.
$$

\section{$\Delta$ (LLR / Cust.}

Panel A: Full Sample Matching

\section{CEB: After - Before \\ Control: After - Before \\ Bias-Corrected ATT}

Number of Observations

Panel B: Overlap Matching

CEB: After - Before

Control: After - Before

Bias-Corrected ATT

Number of Observations

$\begin{array}{cc}-5.99^{* * *} & 1.56^{* * *} \\ -4.55^{* * *} & 1.29^{* * *} \\ -0.71 & 0.64 \\ 48 & 48\end{array}$

$$
\begin{gathered}
-6.46^{* * *} \\
-5.92^{* * *} \\
-0.64
\end{gathered}
$$

\begin{tabular}{|c|c|c|}
\hline$\Delta \log \mathrm{TA}$ & $\begin{array}{c}\Delta \text { Log Cust. } \\
\text { Loans }\end{array}$ & $\begin{array}{c}\Delta \text { Log Total } \\
\text { Securities }\end{array}$ \\
\hline
\end{tabular}

36

$1.94^{* * *}$
$1.97^{* * *}$
0.00
36

36
Asset Shrinking

$$
\begin{gathered}
0.01 \\
0.10^{* * *} \\
-0.12^{* * *} \\
48
\end{gathered}
$$$$
0.02
$$$$
0.17^{* * *}
$$$$
-0.15^{*}
$$

36

0.01
$0.28^{* * *}$
$-0.27^{* *}$

36
0.07

$0.16^{*}$

$-0.09$

36
0.07

48 


\section{Table IX \\ Banks with Low and High Holdings of Subordinated Debt}

This table presents the estimates of the change in core tier 1 ratios and its components for banks with low (Panel A and B) and high (Panel C and D) holdings of subordinated debt. Banks with low (high) holdings of subordinated debt are banks with a below (above) median (9.3\%) share of subordinated debt of total debt. The dependent variables are the change in the core tier 1 ratio, the logarithms of core tier 1 capital, risk-weighted assets and subordinatet debt. In each panel, the first row contains the difference in the outcome variable for Capital Exercise banks (CEB) between the before (2009 and 2010) and the after (2012 and 2013) period, and the second row the difference in the outcome variable for matched control group (Control) banks over the same period. The paper tests for differences-in-means using Welch's two-sample t-test. The third row contains the estimate for the average treatment effect on the treated (ATT) based on the biascorrected Abadie and Imbens (2002) matching estimator. Panel A presents the results for the full sample matching strategy, and Panel B the results for the overlap matching strategy. *, **, and $* * *$ indicate statistical significance at the $10 \%, 5 \%$, and $1 \%$ level respectively.

\begin{tabular}{lcccc} 
& \multicolumn{2}{c}{ Banks with Low Holdings of Subordinated Debt } \\
\cline { 2 - 5 } Dependent Variable & $\Delta$ CT1 Ratio & $\begin{array}{c}\Delta \text { Log CT1 } \\
\text { Capital }\end{array}$ & $\Delta$ Log RWA & $\begin{array}{c}\Delta \text { Log Sub. } \\
\text { Debt }\end{array}$ \\
Panel A: Full Sample Matching & & & \\
CEB: After - Before & $3.67^{* * *}$ & $0.25^{* * *}$ & $-0.08^{* * *}$ & $-0.24^{*}$ \\
Control: After - Before & $2.11^{* * *}$ & $0.15^{* * *}$ & -0.02 & $-0.06^{*}$ \\
Bias-Corrected ATT & $2.75^{* * *}$ & $0.22^{* * *}$ & 0.00 & 0.10 \\
Number of observations & 26 & 26 & 26 & 26 \\
& & & & \\
Panel B: Overlap Matching & $3.99^{* * *}$ & $0.26^{* * *}$ & $-0.10^{* * *}$ & $-0.28^{*}$ \\
CEB: After - Before & $3.64^{* * *}$ & $0.17^{* * *}$ & -0.06 & $-0.46^{* * *}$ \\
Control: After - Before & 0.26 & 0.08 & -0.03 & 0.18 \\
Bias-Corrected ATT & 20 & 20 & 20 & 20 \\
Number of observations & \multicolumn{2}{c}{ Banks with Low Holdings of Subordinated Debt }
\end{tabular}

Panel C: Full Sample Matching

CEB: After - Before

Control: After - Before

Bias-Corrected ATT

Number of observations

Panel D: Overlap Matching

CEB: After - Before

Control: After - Before

Bias-Corrected ATT

Number of observations

$\begin{array}{cccc}2.25^{* * *} & 0.11^{* * *} & -0.13^{* * *} & -0.46^{* *} \\ 1.79^{* * *} & 0.23^{* * *} & 0.05^{* *} & -0.22^{* * *} \\ 3.37^{* *} & -0.12 & -0.59^{* * *} & -0.51^{* * *} \\ 22 & 22 & 22 & 22\end{array}$

$\begin{array}{cccc}1.96^{* *} & 0.09^{*} & -0.13^{* *} & -0.53^{* *} \\ 2.29^{* * *} & 0.32^{* * *} & 0.09^{*} & -0.26^{* *} \\ -0.14 & -0.22^{* * *} & -0.23^{* *} & -0.31 \\ 16 & 16 & 16 & 16\end{array}$




\section{Table X Syndicated Lending: Intensive Margin}

This table presents the estimation results of the change in lending around the 2011 EBA capital exercise from Equation 1 in Section II:

$$
\Delta \log \text { Loan Exposure } \text { Eij }=\beta \cdot \mathrm{CEB}_{b i}+\gamma \cdot X_{b i}+\eta_{i}+\eta_{j}+\epsilon_{b i j}
$$

where $\Delta \log$ Loan $_{\text {Exposure }}$ bij is the change in loan exposure of bank $b$ in country $i$ to firm cluster $j$ between the four quarters before the EBA capital exercise (2010Q3 - 2011Q2) and the four quarters after the capital exercise (2012Q3 - 2013Q2). The variable $C E B_{b i}$ takes on the value of 1 if the bank is a Capital Exercise bank, and 0 otherwise. Bank characteristics include: Log Total Assets, Core Tier 1 Ratio, Customer Loans / Total Assets, Net Interest Income / Operating Revenue, Total Deposits / Total Assets, and Net Income / Total Assets, all as of 2010. $\eta_{j}$ are Borrower Home Country $\times$ Industry (firm cluster) fixed effects and $\eta_{i}$ are bank home country fixed effects. The intensive margin sample includes country-industry firm clusters to which banks lend before and after the capital exercise. Standard errors are clustered at the bank level. ${ }^{*},{ }^{* *}$, and $* * *$ indicate statistical significance at the $10 \%, 5 \%$, and $1 \%$ level respectively.

\begin{tabular}{lccccc}
\hline & & & & & \\
& & $(1)$ & $(3)$ & $(4)$ & $(5)$ \\
CEB & $-0.09^{*}$ & $-0.14^{*}$ & $-0.16^{* *}$ & $-0.16^{* *}$ & $-0.17^{* *}$ \\
& $(0.05)$ & $(0.08)$ & $(0.08)$ & $(0.07)$ & $(0.07)$ \\
& & & & & \\
Bank Home Country FE & YES & YES & YES & YES & YES \\
Bank Characteristics & & YES & YES & YES & YES \\
Borrower Home Country FE & & & YES & YES & \\
Industry FE & & & & YES & \\
Borrower Home Country $\times$ Industry FE & & & & & YES \\
Capital Exercise Banks & 45 & 45 & 45 & 45 & 45 \\
Control Group Banks & 27 & 27 & 27 & 27 & 27 \\
Adjusted $R^{2}$ & & & & & \\
Observations & 0.02 & 0.03 & 0.07 & 0.09 & 0.25 \\
& 2,177 & 2,177 & 2,177 & 2,177 & 2,177 \\
\hline
\end{tabular}


Table XI

Pre-Treatment Characteristics of Firms

This table provides pre-treatment summary statistics on CEB-dependent firms, Non-CEB-dependent firms and control group firms (mean comparisons). CEB-dependent (Non-CEB dependent) firms are firms with an above (below) median (65.0\%) share of their borrowing from Capital Exercise banks in the pre-treatment period. Panel A compares the mean values of 952 CEB-dependent firms and 1006 Non-CEB-dependent firms in the unmatched sample. Panel B compares the 952 CEB dependent firms to the sample of matched control group firms based on the bias-corrected (Abadie and Imbens, 2002) matching estimator. ${ }^{*},{ }^{* *}$ and ${ }^{* * *}$ indicated statistical significance at the $10 \%, 5 \%$, and $1 \%$ level respectively.

\begin{tabular}{ccccccc} 
& Log Total & \multicolumn{3}{c}{ Cash Flow / } & EBITDA / & \\
\# Firms & Assets & Tangibility & Total Assets & Net Worth & Total Assets & Leverage
\end{tabular}

Panel A: Unmatched Sample

CEB-dependent firms

Non-CEB dependent firms

1,006

19.78

0.59

0.07

0.24

19.48

0.56

$0.30^{* * *}$

$0.03^{* * *}$

0.07

0.00

0.25

$-0.01$

0.09

0.09

0.92

Panel B: Matched Sample

CEB-dependent firms

Non-CEB dependent firms 


\section{Table XII}

\section{Firm-Level Outcomes}

This table presents the estimates of the change in firm-level outcomes around the 2011 EBA capital exercise. The dependent variables are the change in the logarithms of total assets, fixed assets and sales. In each panel, the first row contains the difference in the outcome variable for Capital Exercise Bank (CEB) dependent firms between the before (2009 and 2010) and the after (2012 and 2013) period, and the second row the difference in the outcome variable for matched control group (Control) banks over the same period. The paper tests for differences-in-means using Welch's two-sample t-test. The third row contains the estimate for the average treatment effect on the treated (ATT) based on the bias-corrected Abadie and Imbens (2002) matching estimator. Panel A presents the results for all firms in our sample, Panel B the results for unlisted firms in our sample, and Panel $\mathrm{C}$ the results for listed firms in our sample. *, **, and ${ }^{* * *}$ indicate statistical significance at the $10 \%, 5 \%$, and $1 \%$ level respectively.

Dependent Variable

Panel A: All Firms

CEB-dependent firms: After - Before

Control: After - Before

Bias-Corrected ATT

Number of Observations

Panel B: Unlisted Firms

CEB-dependent firms: After - Before

Control: After - Before

Bias-Corrected ATT

Number of Observations

Panel C: Listed Firms

CEB-dependent firms: After - Before

Control: After - Before

Bias-Corrected ATT

Number of Observations
$\Delta$ Log Total Assets

$0.07^{* * *}$
$0.10^{* * *}$
$-0.04^{* *}$
952

$0.04^{* * *}$

$0.10^{* * *}$

$-0.06^{* * *}$

681

$0.13^{* * *}$
$0.10^{* * *}$
0.02
271

$0.13^{* * *}$

0.02

271
$\Delta$ Log Fixed Assets

$\Delta$ Log Sales

$0.07^{* * *}$

$0.12^{* * *}$

$0.10^{* * *}$

$0.14^{* * *}$

$-0.06^{* * *}$

952

$-0.05^{* *}$

952

$0.14^{* * *}$

$0.06^{*}$

$0.11^{* * *}$

$-0.04$

681

$681 \quad 681$




\title{
For Online Publication
}

\author{
Online Appendix for
}

"Bank Response to Higher Capital Requirements: Evidence from a Quasi-Natural Experiment" March 2018 
Table A1

\section{List of Banks in the 2011 EBA Capital Exercise}

This table lists all 61 banks initially included in the 2011 EBA capital exercise. As the paper wants to track the behavior of independent banks over time, we exclude all banks which were acquired during the sample period, all banks which received capital injections during the pre-treatment period and all banks with negative levels of equity. This sample construction procedure finally leaves us with a sample of 48 EBA banks.

Bank

Erste Group Bank AG

Raiffeisen Bank International AG

KBC Bank NV

Bank of Cyprus Public Company Limited

Cyprus Popular Bank Public Co. Ltd.

Danske Bank A/S

Jyske Bank A/S

Nykredit Realkredit A/S

Sydbank A/S

OP Financial Group

BNP Paribas SA

Crédit Agricole Group

Groupe BPCE

Société Générale SA

Bayerische Landesbank

Commerzbank AG

DekaBank Deutsche Girozentrale

Deutsche Bank AG

Deutsche Zentral-Genossenschaftsbank AG

HSH Nordbank AG

Hypo Real Estate Holding AG

Landesbank Baden-Württemberg

Landesbank Berlin Holding AG

Landesbank Hessen-Thüringen Girozentrale

NORD/LB Norddeutsche Landesbank Girozentrale

Westdeutsche Genossenschafts-Zentralbank AG

Allied Irish Banks, Plc

Bank of Ireland

Permanent TSB Group Holdings Plc
Country

Sample

Austria

Austria

Belgium

Cyprus

Cyprus

Denmark

Denmark

Denmark

Denmark

Finland

France

France

France

France

Germany

Germany

Germany

Germany

Germany

Germany

Germany

Germany

Germany

Germany

Germany

Germany

Ireland

Ireland

Ireland

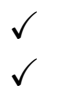

$\checkmark$

$\checkmark$

$\checkmark$

$\checkmark$

$\checkmark$

$\checkmark$

$\checkmark$

$\checkmark$

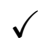

$\checkmark$

$\checkmark$

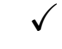

$\checkmark$

$\checkmark$

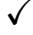


Table A1 (cont.)

Banca Monte dei Paschi di Siena SpA

Banco Popolare Societ Cooperativa

Intesa Sanpaolo SpA

UniCredit SpA

Unione di Banche Italiane SCpA

OTP Bank Nyrt.

Banque et Caisse d'Epargne de l'Etat

Bank of Valletta Plc

ABN AMRO Group NV

ING Bank NV

Rabobank Group

SNS Bank NV

DNB Bank ASA

Powszechna Kasa Oszczednosci Bank Polski SA

Banco BPI SA

Banco Comercial Portugus SA

Caixa Geral de Depsitos SA

Espirito Santo Financial Group SA

Nova Kreditna banka Maribor d.d.

Nova Ljubljanska Banka d.d.

Banco Bilbao Vizcaya Argentaria, SA

Banco Popular Espanol SA

Banco Santander SA

La Caixa

Nordea Bank AB

Skandinaviska Enskilda Banken AB

Svenska Handelsbanken AB

Swedbank AB

Barclays Plc

HSBC Holdings Plc

Lloyds Banking Group Plc

Royal Bank of Scotland Group Plc

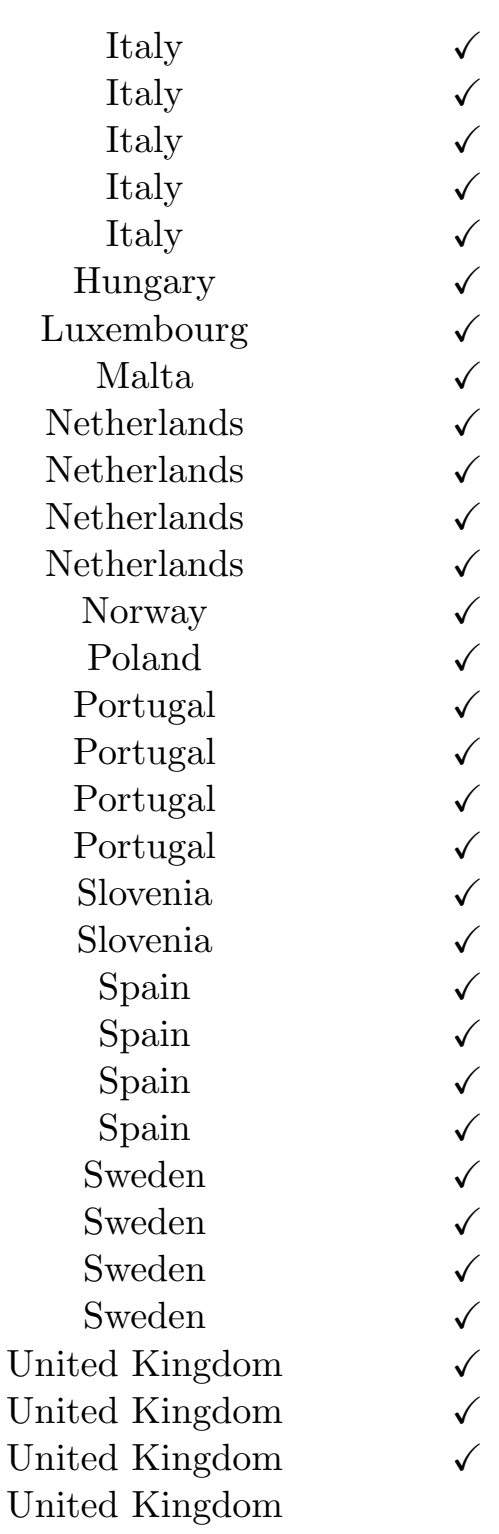




\section{Table A2 \\ Variable Definitions}

This table describes all variables used in the paper. All bank-level variables in Panel A are obtained from the SNL Financial database, all loan-level variables in Panel B are obtained from the Thomson Reuters LPCs Dealscan database, and all firm-level variables in Panel C are obtained from Bureau van Dijk's Amadeus Financials database.

Variable

Panel A: Bank-Level Analysis

Core Tier 1 Capital Ratio (CT1 Ratio)

Log Core Tier 1 Capital

Log RWA

Log Total Assets

Deposits / TA

Loans / TA

NII / Op. Rev.

Net Inc. / TA

Panel B: Loan-Level Analysis

$\Delta$ Log Loan Exposure

Entry (Online Appendix)

Exit (Online Appendix)

Panel C: Firm-Level Analysis

Log Total Assets

Log Fixed Assets

Log Sales

Tangibility

Cash Flow/TA

Net Worth

EBITDA/TA

Leverage
Definition

Core Tier 1 Capital / Risk-Weighted Assets

Natural Logarithm of Core Tier 1 Capital

Natural Logarithm of Risk-Weighted Assets

Natural Logarithm of Total Assets

Total Deposits / Total Assets

Customer Loans / Total Assets

Net Interest Income / Operating Revenue

Net Income / Total Assets

Change in the natural logarithm of the loan exposure of bank $b$ in country $i$ to firm cluster $j$ between the period before (2010Q3-2011Q2)

$=1$ if bank b in country i starts lending to firm cluster $\mathrm{j}$ after the EBA capital exercise, and 0 otherwise $=1$ if bank $\mathrm{b}$ in country i stops lending to firm cluster $\mathrm{j}$ after the EBA capital exercise, and 0 otherwise

Natural Logarithm of Total Assets

Natural Logarithm of Fixed Assets

Natural Logarithm of Firm Sales

Fixed Assets / Total Assets

Cash Flow / Total Assets

Total Shareholder Funds \& Liabilities - Current \& Non-Current Liabilities-Cash TotalAssets

EBITDA / Total Assets

Total Assets - Total Shareholder Funds: Capital TotalAssets 
Table A3

\section{Components of Risk-Weighted Assets and Core Tier 1 Capital}

This table shows the composition of core tier 1 capital and risk-weighted assets (RWA) according to Basel 2. Risk-weighted assets consist of risk-weighted assets for credit risk (cRWA), market risk (mRWA) and operational risk (oRWA). Credit risk-weighted assets include risk-weighted assets for corporate exposures, retail exposures, and sovereign exposures. Corporate exposures are debt obligations of a corporation, partnership or proprietorship (excl. SME exposures). Retail exposures are exposures to individuals, residential mortgage loans, loans extended to SMEs. Sovereign exposures include all exposures to counterparties treated as sovereigns. (BIS, 2005). Core tier 1 capital consists of tier 1 common equity minus regulatory adjustments. Tier 1 common equity includes the share capital, share premium, retained earnings and other items, like minority interests. Regulatory adjustments that are deducted from tier 1 common equity are for example goodwill, deferred tax assets, and unrealized gains on securities held for sale.

\begin{tabular}{|c|c|c|c|}
\hline & Risk-Weighted Assets & & Core Tier 1 Capital \\
\hline $\begin{array}{l}+ \\
+\end{array}$ & $\begin{array}{l}\text { RWA for Corporate Exposures } \\
\text { RWA for Retail Exposures } \\
\text { RWA for Sovereign Exposures }\end{array}$ & $\begin{array}{l}+ \\
+\end{array}$ & $\begin{array}{l}\text { Share Capital \& Share Premium } \\
\text { Retained Earnings } \\
\text { Other Components }\end{array}$ \\
\hline$=$ & RWA for Credit Risk & $=$ & Tier 1 Common Equity \\
\hline $\begin{array}{l}+ \\
+\end{array}$ & $\begin{array}{l}\text { RWA for Market Risk } \\
\text { RWA for Operational Risk }\end{array}$ & + & Regulatory Adjustments \\
\hline$=$ & Total Risk-Weighted Assets & $=$ & Core Tier 1 Capital \\
\hline
\end{tabular}


(a) Full: CT1 Ratio

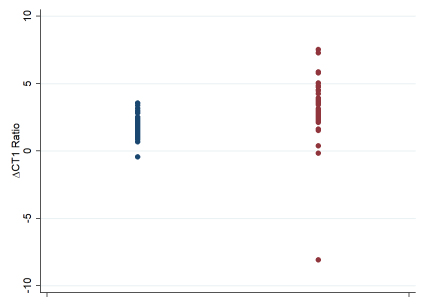

(d) Overlap: CT1 Ratio

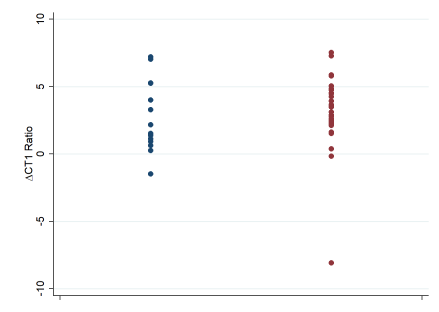

(g) Within Country: CT1 Ratio

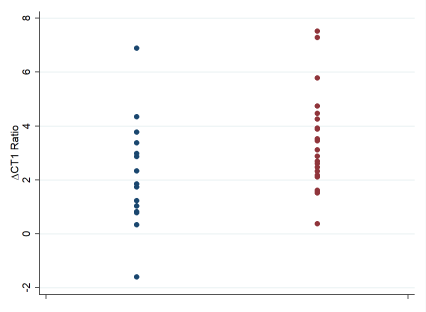

(j) Within Region: CT1 Ratio

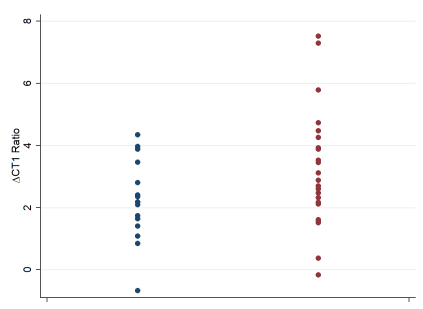

(b) Full: CT1 Capital

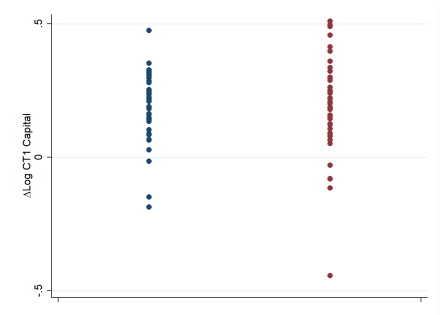

(e) Overlap: CT1 Capital

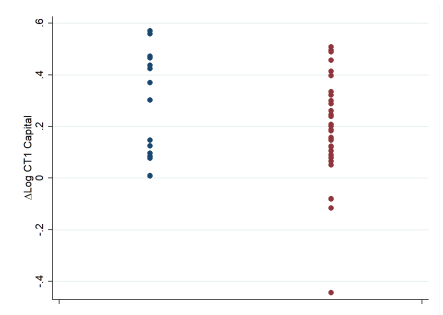

(h) Within Country: CT1 Capital

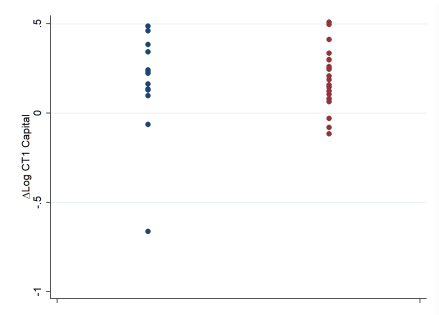

(k) Within Region: CT1 Capital

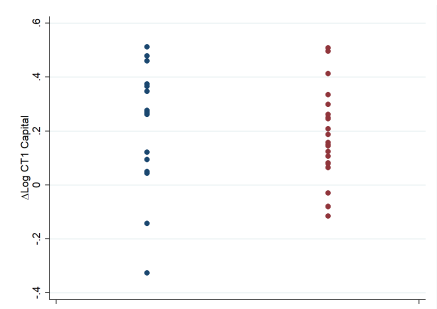

(c) Full: RWA

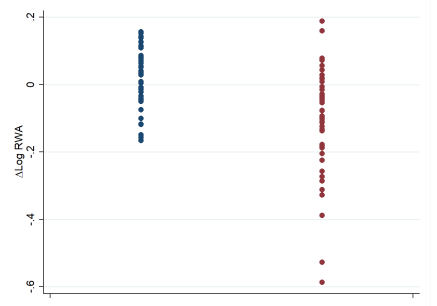

(f) Overlap: RWA

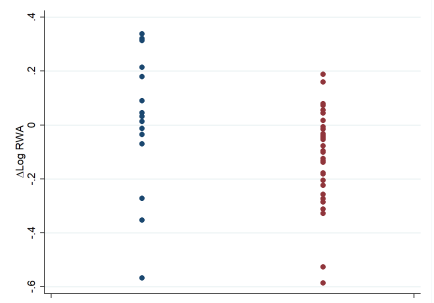

(i) Within Country: RWA

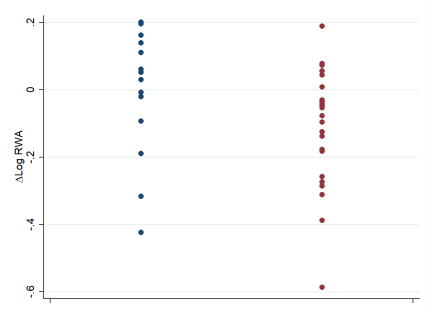

(l) Within Region: RWA

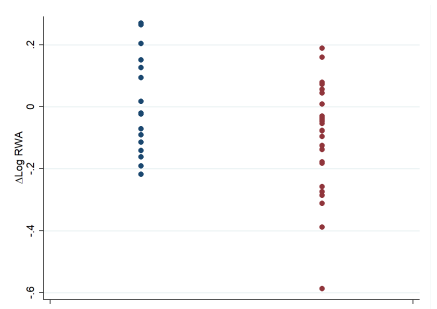

Figure A1. Changes in Core Tier 1 Ratios: Scatter Plots. This figure shows scatter plots for the dependent variables of Table V ( $\Delta$ CT1 Ratio, $\Delta$ Log CT1 Capital, $\Delta$ Log RWA) for Capital Exercise Banks (red dots at the right-hand side in each panel) and Non-Capital Exercise Banks (blue dots at the left-hand side in each panel) for all four matching strategies. 


\section{Bank-Level Robustness Check: Difference-in-Differences Regression Analysis}

In the bank-level part of the paper, we employ a difference-in-differences matching approach. As a robustness check, Table A4 replicates

all results of the bank-level part of the paper using a regression-based approach.

Table A4

\section{Bank-Level Difference-in-Differences Regression Analysis}

This appendix presents the estimation results of the following difference-in-difference regression:

$$
Y_{i c}=\alpha+\beta \times \mathrm{CEB}_{i c}+\gamma \times X_{i}+\eta_{c}+\epsilon_{i c}
$$

where $Y_{i c}$ is the change in the outcome variable of bank $i$ in country $c$. The variable $C E B_{i c}$ takes on the value 1 for the 48 Capital Exercise banks and 0 for the 144 non-Capital Exercise banks in our full sample. The dependent variables are the change in the core tier 1 ratio, the change in the logarithm of core tier 1 capital, and the change in the logarithm of risk-weighted assets between the before (2009 and 2010) and the after (2012 and 2013) period. Control variables are Total Assets, CT1 Capital Ratio, Total Deposits / TA,

Customer Loans / TA, Net Interest Income / Operating Revenue, and Net Income / TA as of end of 2010. Standard errors are clustered at the country level. ${ }^{*}, * *$, and $* * *$ indicate statistical significance at the $10 \%, 5 \%$, and $1 \%$ level respectively.

Panel A: Replication Table $V$

Dependent Variable

CEB

Bank Characteristics

Bank Home Country FE

Number of Observations

$R^{2}$
$\Delta$ CT1 Ratio

$\begin{array}{ccc}1.60^{* * *} & 1.07^{* *} & 1.40^{* * *} \\ (0.43) & (0.51) & (0.47) \\ & & \\ & \text { YES } & \text { YES } \\ & & \text { YES } \\ 192 & 192 & 192 \\ 0.07 & 0.21 & 0.40\end{array}$

$\Delta$ Log CT1 Capital

$\begin{array}{ccc}0.00 & 0.01 & 0.05 \\ (0.04) & (0.04) & (0.06) \\ & & \\ & \text { YES } & \text { YES } \\ & & \text { YES } \\ & & \\ 192 & 192 & 192 \\ 0.00 & 0.07 & 0.30\end{array}$

$\Delta$ Log CT1 RWA

$\begin{array}{ccc}-0.16^{* * *} & -0.11^{* *} & -0.10 \\ (0.04) & (0.04) & (0.06) \\ & & \\ & \text { YES } & \text { YES } \\ & & \text { YES } \\ 192 & 192 & 192 \\ 0.10 & 0.25 & 0.45\end{array}$


Table A4 (cont.)

Panel B: Replication Table VI

Dependent Variable

CEB

Bank Characteristics

Bank Home Country FE

Number of Observations

$R^{2}$

Dependent Variable

CEB

Bank Characteristics

Bank Home Country FE

Number of Observations

$R^{2}$

$\Delta \log \mathrm{T}$
-0.07
$(0.05)$

$-0.04$

-0.04
$(0.05)$

$-0.01$

(0.08)

YES

YES

YES

187

0.01

187

187

0.31

$\Delta$ (Regulatory Adj./CT1 Capital)

$\begin{array}{lll}-0.10 & -0.06 \quad-0.05\end{array}$

(0.06)

$(0.05)$

(0.08)

YES YES

YES

$\begin{array}{lll}187 & 187 & 187\end{array}$

$\begin{array}{lll}0.02 & 0.03 & 0.12\end{array}$

$\Delta$ Log Share Cap. \& Prem.

$\begin{array}{ccc}-0.10 & -0.04 & -0.14 \\ (0.13) & (0.14) & (0.16) \\ & & \\ & \text { YES } & \text { YES } \\ & & \text { YES } \\ & & \\ 162 & 162 & 162 \\ 0.01 & 0.03 & 0.12\end{array}$


Table A4 (cont.)

Panel C: Replication Table VII

Dependent Variable

CEB

Bank Home Country FE

\begin{tabular}{ccc}
\multicolumn{3}{c}{$\Delta$ Log Credit RWA } \\
\hline$-0.18^{* * *}$ & $-0.12^{* * *}$ & $-0.12^{*}$ \\
$(0.04)$ & $(0.03)$ & $(0.06)$
\end{tabular}

Number of Observations

$R^{2}$

YES YES

$185 \quad 185 \quad 185$

$\begin{array}{lll}0.11 & 0.25 & 0.46\end{array}$

\begin{tabular}{ccc}
\multicolumn{3}{c}{$\Delta$ Log Market RWA } \\
\hline 0.11 & 0.21 & 0.09 \\
$(0.25)$ & $(0.31)$ & $(0.34)$ \\
& & \\
& YES & YES \\
& & YES \\
145 & 145 & 145 \\
0.00 & 0.03 & 0.39
\end{tabular}

Panel D: Replication Table VIII

Dependent Variable

CEB

Bank Characteristics

Bank Home Country FE

Number of Observations $R^{2}$

$$
\Delta \text { Log Corporate Exposures }
$$

$\begin{array}{lll}-0.15 & -0.19^{*} & -0.06\end{array}$

(0.12)

(0.11)

(0.15)

YES

YES

YES

85
0.02
$\Delta$ Log Retail Exposures

\begin{tabular}{ccc}
\hline & & \\
$-0.15^{* *}$ & -0.14 & $-0.34^{* * *}$ \\
$(0.07)$ & $(0.08)$ & $(0.10)$ \\
& & \\
& YES & YES \\
& & YES
\end{tabular}

$\Delta$ Log Operational RWA

$\begin{array}{ccc}-0.06 & -0.05 & -0.00 \\ (0.04) & (0.03) & (0.04) \\ & & \\ & \text { YES } & \text { YES } \\ & & \text { YES } \\ & & \\ 183 & 183 & 183 \\ 0.01 & 0.07 & 0.24\end{array}$

$\Delta$ Log Other Exposures

\begin{tabular}{ccc}
\hline$-0.69^{* * *}$ & $-0.34^{* *}$ & $-0.46^{* *}$ \\
$(0.25)$ & $(0.15)$ & $(0.14)$ \\
& & \\
& YES & YES \\
& & YES \\
& & \\
84 & 84 & 84 \\
0.12 & 0.41 & 0.65
\end{tabular}


Table A4 (cont.)

Panel E: Replication Table IX

Dependent Variable

CEB

Bank Home Country FE

Number of Observations

$R^{2}$

Dependent Variable

ç

$\Delta$
-2.21
$(1.32)$

$\Delta(\mathrm{RWA} / \mathrm{TA})$

$-0.70 \quad-2.30$

(1.62) (1.70)

YES

YES

192

0.01

192

0.12

192
0.35

$$
-
$$

$\Delta$ Log Total Assets

$\begin{array}{ccc}-0.11^{* *} & -0.11^{* *} & -0.07 \\ (0.04) & (0.05) & (0.05)\end{array}$

$\Delta$ Log Customer Loans

$\begin{array}{ccc}-0.12^{* * *} & -0.13^{* * *} & -0.10^{* *} \\ (0.04) & (0.03) & (0.04)\end{array}$

YES YES

Bank Characteristics

Bank Home Country FE

Number of Observations

$R^{2}$

0.05

192

YES

YES

YES

YES

$\begin{array}{lll}192 & 192 & 192\end{array}$

$\begin{array}{lll}192 & 192 & 192 \\ 0.04 & 0.22 & 0.51\end{array}$

192
0.45

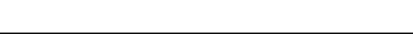




\section{Bank-Level Robustness Check: Regression Discontinuity Design}

In the bank-level part of the paper, we employ a difference-in-differences matching approach. The empirical setting of the capital exercise also seems to lend itself to a regression discontinuity (RD) design. Given the EBA's explicit selection rule based on bank size, the running variable is defined as bank size as a fraction of the country-specific size cutoff for being included in the capital exercise. The RD approach then exploits the country-specific selection threshold by comparing the change in core tier 1 ratios for banks just above and just below the threshold. Figure A2 shows the bank size distribution in each country normalized by the country-specific cutoff.

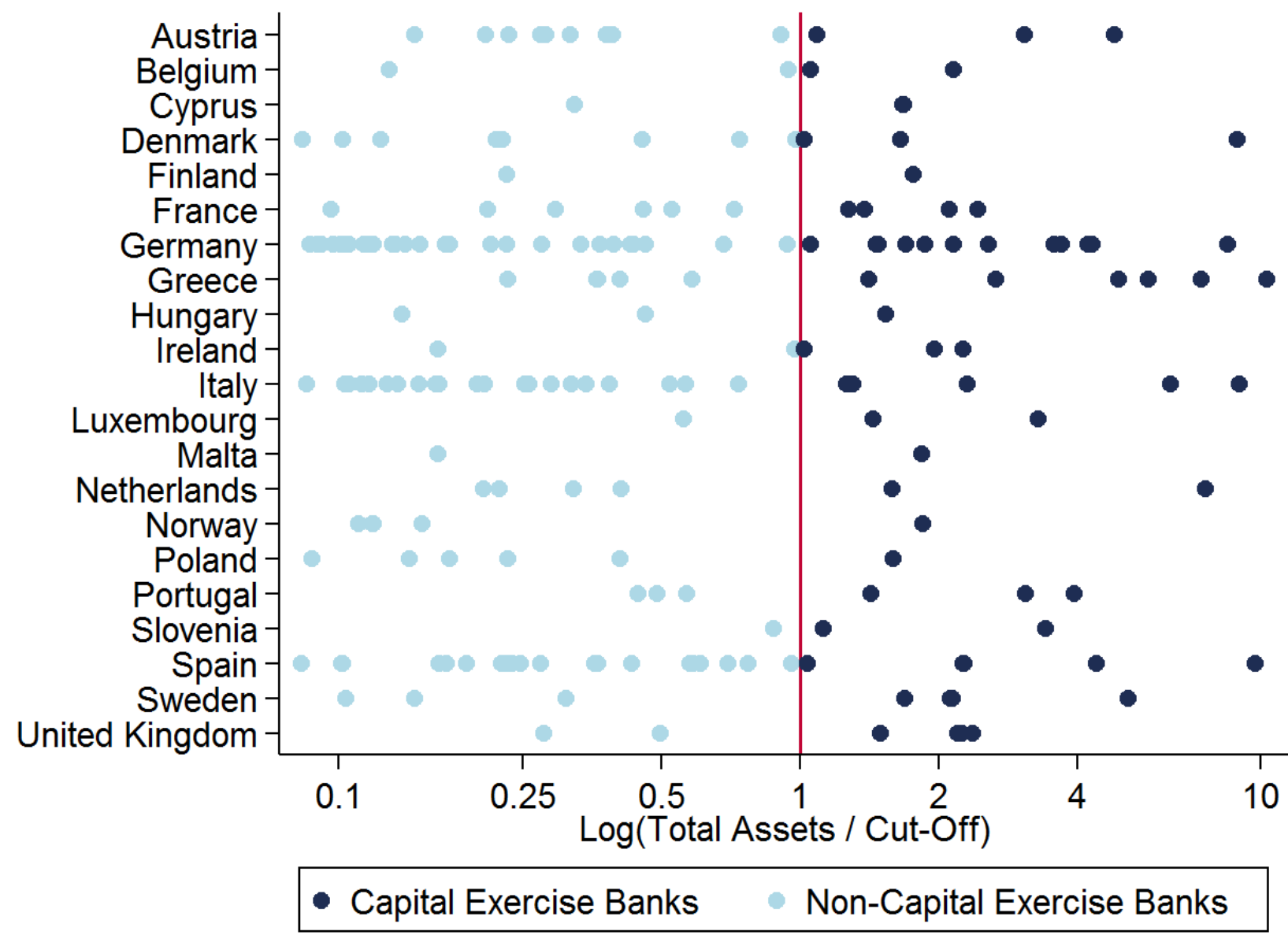

Figure A2. Distance from the Cutoff. This figure shows the bank size distribution normalized by the country-specific selection cutoff (total assets as of end of 2010 / country-specific cutoff) of Capital Exercise banks and Non-Capital Exercise banks by country. The graph includes all ultimate parent banks headquartered in EBA supervised countries included in the SNL database. 
In some countries (for example Belgium, Denmark, Ireland, and Spain), the smallest Capital Exercise bank and the largest Non-Capital Exercise bank have a similar size. In other countries (for example the Netherlands), this distance is bigger. The internal validity of an RD approach relies on two identifying assumptions: That banks could not manipulate the running variable and therefore whether they are included in the capital exercise or not; and that other bank characteristics affecting the outcome variables are continuous around the cutoff. Since the EBA capital exercise came unexpected in October 2011 and since selection into the exercise was based on banks' total assets as of end of 2010, it is unlikely that banks could manipulate their inclusion in the capital exercise. We test for manipulation using the procedure proposed in Cattaneo, Jansson, and Ma (2017). The results reject the manipulation hypothesis. Assessing the continuity of other bank characteristics around the cutoff requires the choice of a bandwidth, that is a definition of what it means to be "just above or just below the cutoff". Bandwidth selection is an important decision in the implementation of an RD design. For our analysis, we use the optimal bandwidth selection procedure by Calonico, Cattaneo, and Titiunik (2014). Figure A3 plots six bank characteristics (Log Total Assets, CT1 Capital Ratio, Total Loans/Total Assets, Net Interest Income/Operating Revenue, Total Deposits/Total Assets, Net Income / Total Assets) against the running variable, defined as bank size as a fraction of the country-specific size cutoff. The solid vertical lines indicate the threshold for being included in the Capital Exercise and the two dashed vertical lines indicate the optimal bandwidth based on Calonico, Cattaneo, and Titiunik (2014), which results in a sample of 22 banks around the cutoff. The figure shows that the bank characteristics do not clearly jump around the threshold, but also that there is a large variation in bank characteristics close to the threshold. The small number of observations, combined with large variation in bank characteristics around the cutoff, makes inference based on an RD design problematic in our setting. Table A5 presents the results for the RD approach. Panel A and Panel B use the full sample of banks and include a first-order polynomial and second-order polynomial in the running variable, respectively. We find results very similar to our matching methodology. Panel $\mathrm{C}$ then successively reduces the bandwidth. As discussed above, using the optimal bandwidth based on Calonico, Cattaneo, and Titiunik (2014) results in a sample of 22 banks. While the findings point in the same direction as our matching results, coefficients and standard errors become very large in magnitude, and the results are thus of limited informativeness. 
(a) Log Total Assets

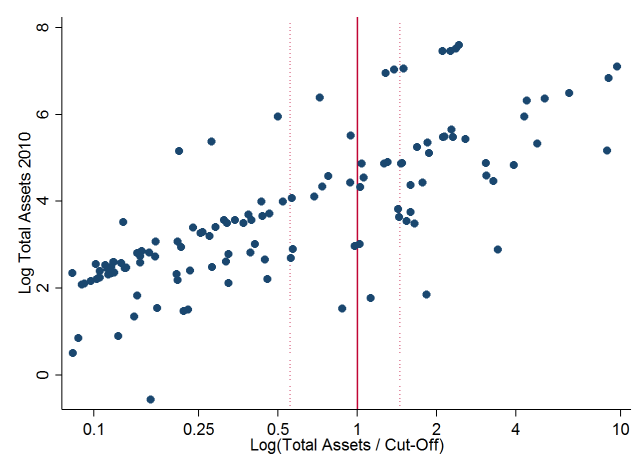

(c) Total Deposits / Total Assets

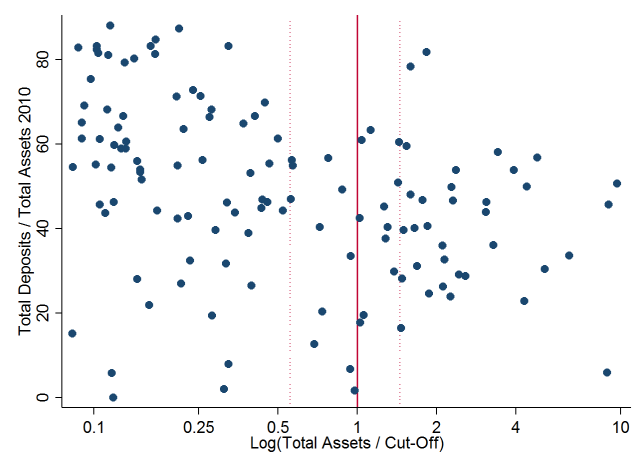

(e) Net Interest Income / Operating Rev.

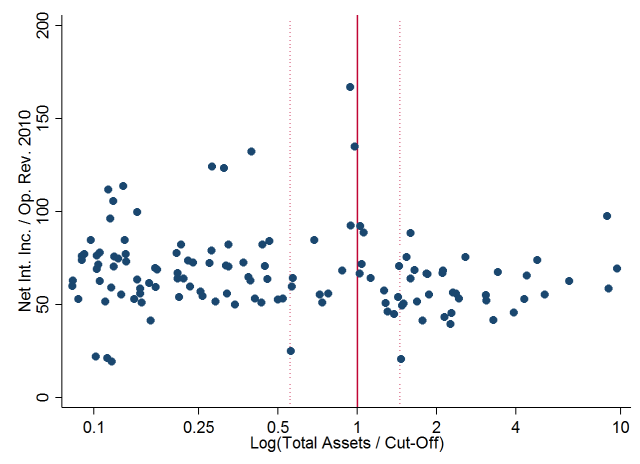

(b) Core Tier 1 Ratio

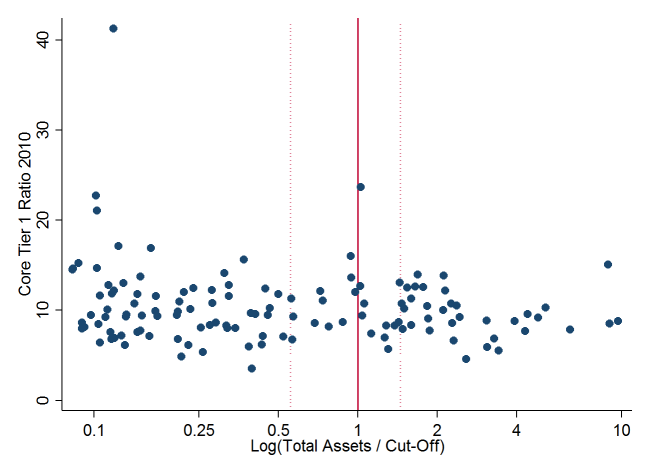

(d) Customer Loans / Total Assets

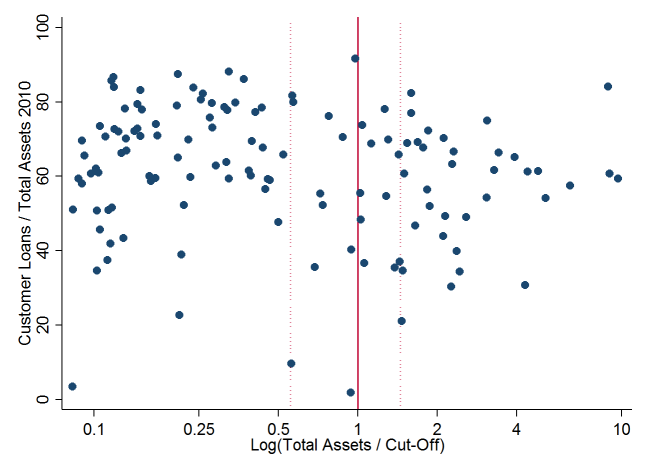

(f) Net Income / Total Assets

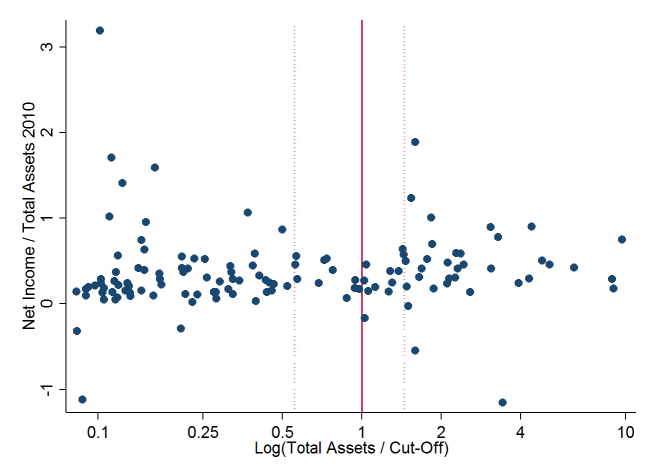

Figure A3. Bank Characteristics around the Cutoff. This figure shows the bank characteristics as a function of the distance to the cutoff (total assets / country specific cutoff). The red dotted line indicate the optimal bandwidth based on Calonico, Cattaneo, and Titiunik (2014). 
Table A5

\section{Regression Discontinuity Results}

This table presents the estimates of the change in core tier 1 ratios and its components using a regression discontinuity approach. The dependent variables are the change in the core tier 1 (CT1) ratio, the logarithm of core tier 1 (CT1) capital, and the logarithm of the risk-weighted assets (RWA). The variable Capital Exercise Bank takes on the value of 1 Capital Exercise Bank if the bank size in total assets is larger than the country specific cutoff, and 0 otherwise. The sample is based on all Capital Exercise banks (48) and control group banks (144). Standard errors are robust and clustered at the country level. ${ }^{*},{ }^{* *}$, and $* * *$ indicate statistical significance at the $10 \%, 5 \%$, and $1 \%$ level respectively.

Panel A: First-Order Polynomials

Dependent Variable

Capital Exercise Bank

\begin{tabular}{ccc}
\multicolumn{3}{c}{$\Delta$ CT1 Ratio } \\
\hline \multirow{2}{*}{$1.71^{* * *}$} & $1.07^{*}$ & $1.45^{* * *}$ \\
$(0.55)$ & $(0.56)$ & $(0.46)$ \\
& & \\
YES & YES & YES \\
& YES & YES \\
& & YES \\
& & \\
192 & 192 & 192 \\
0.08 & 0.20 & 0.38
\end{tabular}

Number of Observation

$R^{2}$

First Order Polynomial

Bank Characteristics

Country FE

Panel B: Second-Order Polynomials

Capital Exercise Bank

$$
1.72^{*}
$$$$
\text { (0.86) }
$$

1.04
$(0.85)$

$1.80^{* * *}$

$(0.47)$

First Order Polynomial

Bank Characteristics

YES

Country FE

Number of Observations

$R^{2}$

192

0.08

\section{YES}

YES

YES

192

0.38
$\Delta$ Log CT1 Capital

$\begin{array}{ccc}0.05 & -0.05 & 0.01 \\ (0.05) & (0.06) & (0.06) \\ & & \\ \text { YES } & \text { YES } & \text { YES } \\ & \text { YES } & \text { YES } \\ & & \text { YES } \\ & & \\ 192 & 192 & 192 \\ 0.02 & 0.08 & 0.31\end{array}$

\begin{tabular}{ccc}
\multicolumn{3}{c}{$\Delta$ Log RWA } \\
\hline \multirow{2}{*}{$-0.21^{* * *}$} & $-0.16^{* * *}$ & $-0.13^{*}$ \\
$(0.05)$ & $(0.05)$ & $(0.06)$ \\
& & \\
YES & YES & YES \\
& YES & YES \\
& & YES \\
& & \\
192 & 192 & 192 \\
0.11 & 0.23 & 0.42
\end{tabular}

$\begin{array}{lccccc}-0.05 & -0.04 & 0.03 & -0.21^{* * *} & -0.14^{* * *} & -0.11 \\ (0.08) & (0.09) & (0.09) & (0.05) & (0.05) & (0.06) \\ & & & & & \\ \text { YES } & \text { YES } & \text { YES } & \text { YES } & \text { YES } & \text { YES } \\ & \text { YES } & \text { YES } & & \text { YES } & \text { YES } \\ & & \text { YES } & & & \text { YES } \\ & & & & & \\ 192 & 192 & 192 & 192 & 192 & 192 \\ 0.02 & 0.08 & 0.31 & 0.12 & 0.23 & 0.42\end{array}$


Table A5 (cont.)

Panel C: Different Bandwidths

Dependent Variable

Bandwidth

Capital Exercise Bank

First Order Polynomial
Bank Characteristics

Country FE

Number of Observations

$R^{2}$
$\Delta$ CT1 Ratio

$[-\infty ;+\infty][0.25 ; 4.00][0.54 ; 1.46$

$\begin{array}{ccc}1.45^{* * *} & 1.07 & 12.75 \\ (0.45) & (2.43 & (58.65)\end{array}$

YES

YES

YES

192

0.38

[-

$\Delta$ Log CT1 Capital

$-\infty ;+\infty][0.25 ; 4.00][0.54 ; 1.46]$

0.01

$(0.06)$

$-0.16$

(0.21)

$$
-5.60
$$

(5.52)

YES

YES

YES

YES

YES

YES

YES

YES

YES

192

0.31
72

0.56
22

0.86

\begin{tabular}{ccc}
\multicolumn{3}{c}{$\Delta$ Log RWA } \\
\hline$[-\infty ;+\infty]$ & {$[0.25 ; 4.00]$} & {$[0.54 ; 1.46]$} \\
$-0.13^{*}$ & -0.20 & $-6.69^{*}$ \\
$(0.06)$ & $(0.25)$ & $(3.35)$ \\
& & \\
YES & YES & YES \\
YES & YES & YES \\
YES & YES & YES \\
& & \\
192 & 72 & 22 \\
0.42 & 0.54 & 0.84 \\
& &
\end{tabular}




\section{Bank-Level Robustness Check: GIIPS-Indicator Interaction Term Regression}

Our within region matching strategy in Section III.A.2 suggests that our results are not driven by the European sovereign debt crisis which mainly affected the economies of Greece, Ireland, Italy, Portugal, and Spain (GIIPS countries). Table A6 provides a further regression-based test estimating the following regression specification:

$$
Y_{i c}=\alpha+\beta \times \mathrm{CEB}_{i c}+\gamma \times \mathrm{GIIPS}_{i c}+\delta \times\left(\mathrm{CEB}_{i c} \times \mathrm{GIIPS}_{i c}\right)+\theta \times X_{i c}+\epsilon_{i c}
$$

where $Y_{i c}$ is the change in the outcome variable of bank $i$ in country $c$. The variable $C E B_{i c}$ takes on the value 1 for the 48 Capital Exercise banks and 0 for the 144 non-Capital Exercise banks in our full sample and the variable GIIPS $S_{i c}$ takes on the value 1 if bank $i$ is based in a GIIPS country, and 0 otherwise. As in Section III.A.2, control variables $X_{i}$ are Total Assets, CT1 Capital Ratio, Total Deposits / TA, Customer Loans / TA, Net Interest Income / Operating Revenue, and Net Income / TA as of end of 2010. Standard errors are clustered at the country level. *,**, and $* * *$ indicate statistical significance at the $10 \%, 5 \%$, and $1 \%$ level respectively. If our results were exclusively driven by banks from GIIPS countries, we would expect the coefficient $\beta$ to be insignificant. The results in Table A6 suggest that this is not the case.

Table A6

\section{Bank-Level Regression with GIIPS Indicator}

\begin{tabular}{lccc}
\hline \multirow{2}{*}{ Dependent Variable } & $\Delta$ CT1 Ratio & $\Delta$ Log CT1 & $\Delta$ Log CT1 \\
& & Capital & RWA \\
CEB & $1.19^{* *}$ & -0.08 & $-0.10^{* *}$ \\
GIIPS Indicator & $(0.59)$ & $(0.06)$ & $(0.05)$ \\
& -0.24 & -0.04 & 0.02 \\
CEB $\times$ GIIPS Indicator & $(0.54)$ & $(0.05)$ & $(0.05)$ \\
& -0.08 & 0.02 & -0.08 \\
Bank Characteristics & $(0.94)$ & $(0.09)$ & $(0.08)$ \\
Number of Observations & & & YES \\
Adjusted $R^{2}$ & YES & YES & 192 \\
& 192 & 192 & 0.19 \\
\hline
\end{tabular}




\section{Bank-Level Robustness Check: Placebo Test for the European Sovereign Debt Crisis}

Our within region matching strategy in Section III.A.2 suggests that our results are not driven by the European sovereign debt crisis. Nevertheless, there may still be a lingering concern that our results might be driven by Capital Exercise banks' exposure to the European sovereign debt crisis, which started in 2010 (Popov and Van Horen, 2015). Table A6 provides a placebo matching exercise for the period around the start of the sovereign debt crisis (2009-2010). If our results were driven by banks' exposure to the European sovereign debt crisis, we would expect to find significant results for this placebo period. The results in Table A6 suggest that this is not the case. While Capital Exercise banks reduced their risk-weighted assets by 6 percentage points more than banks in the matched control group, this change is smaller in magnitude compared to the risk-weighted assets reduction of 16 percentage points in Section III and not significant at the $5 \%$ level.

\section{Table A7}

\section{Placebo Test: Changes in Core Tier 1 Ratios Between 2009-2010}

This table presents the estimates of the change in core tier 1 ratios and its components over the placebo period. The dependent variables are the change in the core tier 1 (CT1) ratio, the logarithm of core tier 1 (CT1) capital, and the logarithm of the risk-weighted assets (RWA). The first row contains the difference in the outcome variable for Capital Exercise banks (CEB) between 2009 and 2010 , and the second row the difference in the outcome variable for matched control group (Control) banks over the same period. The paper tests for differences-in-means using Welch's two-sample t-test. The third row contains the estimate for the average treatment effect on the treated (ATT) based on the bias-corrected Abadie and Imbens (2002) matching estimator. * ${ }^{* *}$, and *** indicate statistical significance at the $10 \%, 5 \%$, and $1 \%$ level respectively.

\begin{tabular}{lccc} 
Dependent Variable & $\Delta$ CT1 Ratio & $\begin{array}{c}\Delta \text { Log CT1 } \\
\text { Capital }\end{array}$ & $\Delta$ Log RWA \\
CEB: After - Before & 0.53 & $0.06^{* * *}$ & 0.01 \\
Control: After - Before & 0.55 & $0.09^{* * *}$ & $0.03^{* *}$ \\
Bias-Corrected ATT & 0.13 & -0.03 & $-0.06^{*}$ \\
Number of Observations & 48 & 48 & 48 \\
& & & \\
\hline
\end{tabular}




\section{Extended Bank-Level Analysis: Strongly versus Weakly Capitalized Banks}

The EBA capital exercise required Capital Exercise banks to increase their core tier 1 ratios to 9\% over the period from December 2011 to June 2012. Capital Exercise banks, which already met this criterion in December 2011, also faced higher capital requirements, but were not required by the EBA to further increase their core tier 1 ratios beyond the target ratio of $9 \%$. Therefore, our results should be driven by weakly capitalized Capital Exercise banks. To test this prediction, we divide the sample into a subsample of banks with a pre-treatment core tier 1 ratio below $9 \%$ (exante below) and a subsample of banks with a pre-treatment core tier 1 ratio above or equal to $9 \%$ (ex-ante above). Within these subsamples, we employ the same matching procedure as before and match four Non-Capital Exercise banks to each Capital Exercise bank based on the six matching covariates. Panel A of Table A8 shows the results for the subsample of weakly capitalized banks, and Panel B of Table A8 the results for the subsample of strongly capitalized banks. As expected, our results are stronger for banks with a pre-treatment core tier 1 ratio below $9 \%$. Within the subsample of weakly capitalized banks, the unconditional difference in the increase in core tier 1 ratios is 2.03 percentage points (3.75 percentage points for Capital Exercise banks versus 1.72 percentage points for Non-Capital Exercise banks) compared to only 0.30 percentage points in the subsample of strongly capitalized banks (2.40 percentage points for Capital Exercise banks versus 2.10 percentage points for Non-Capital Exercise banks). This differential increase in core tier 1 ratios is driven by an unconditional difference in the reduction of risk-weighted assets of 20 percentage points (-18 percent for Capital Exercise banks versus +2 percent for Non-Capital Exercise banks) which is higher than the unconditional difference in the full sample and higher than the estimate in the subsample of strongly capitalized banks. Although sufficiently capitalized Capital Exercise banks did not have to increase their core tier 1 ratio in response to the capital exercise, they might have done so for precautionary reasons and in line with the buffer view of bank capital structure Gropp and Heider (2010). 


\section{Table A8 \\ Weakly and Strongly Capitalized Banks}

This table presents the estimates of the change in core tier 1 ratios and its components for the subsample of weakly (Panel A) and strongly (Panel B) capitalized banks. Banks are defined as weakly (strongly) capitalized if they exhibit a core tier 1 ratio below (above) $9 \%$ as of end of 2010 prior to the capital exercise. The dependent variables are the change in the core tier 1 (CT1) ratio, the logarithm of core tier 1 (CT1) capital, and the logarithm of the risk-weighted assets (RWA). In each panel, the first row contains the difference in the outcome variable for Capital Exercise banks (CEB) between the before (2009 and 2010) and the after (2012 and 2013) period, and the second row the difference in the outcome variable for matched control group (Control) banks over the same period. The paper tests for differences-in-means using Welch's two-sample t-test. The third row contains the estimate for the average treatment effect on the treated (ATT) based on the bias-corrected Abadie and Imbens (2002) matching estimator. *, **, and *** indicate statistical significance at the $10 \%, 5 \%$, and $1 \%$ level respectively.

Dependent Variable

Panel A: Weakly Capitalized Banks

CEB: After - Before

Control: After - Before

Bias-Corrected ATT

Number of Observations

Panel B: Strongly Capitalized Banks

CEB: After - Before

Control: After - Before

Bias-Corrected ATT

Number of Observations
$\Delta$ CT1 Ratio

\section{$\Delta \log \mathrm{CT} 1$ \\ Capital}

\section{$\Delta \log$ RWA}

$3.75^{* * *}$

$1.72^{* * *}$

$-0.09$

22
$0.21^{* * *}$
$0.20^{* * *}$
$-0.98^{* * *}$
22
$-0.18^{* * *}$
0.02
$-1.02^{* * *}$
22

$\begin{array}{ccc}2.40^{* * *} & 0.16^{* * *} & -0.04^{*} \\ 2.10^{* * *} & 0.20^{* * *} & 0.03^{*} \\ 1.24^{*} & 0.02 & -0.10^{* *} \\ 26 & 26 & 26\end{array}$




\section{Extended Bank-Level Analysis: Stock Price and Bond Price Event Studies}

In Section III.A.5 we establish debt overhang as the reason Capital Exercise banks were reluctant to raise new equity. As an alternative explanation, Capital Exercise banks could also be reluctant to issue new equity due to asymmetric information concerns. We therefore conduct event studies on banks' stock and bond prices around the announcement dates of seasoned equity offerings. For the stock price event studies, we collect data on the announcement dates of common equity issuances of Capital Exercise and Non-Capital Exercise banks from the SNL Capital Issuance Database. Furthermore, we collect data on banks' stock prices and on the MSCI Europe Financials Index, which we use as a market proxy. We then calculate the cumulative abnormal stock returns around 79 seasoned equity offerings of Capital Exercise Banks (47) and Control Group Banks (32) during the sample period from 2009 and 2013. During the period of the capital exercise from 2011-Q3 to 2012-Q2, there were 7 equity issuances from Capital Exercise banks and 6 from banks in the matched control group. Panel A of Table A9 reports the results of the stock price event study for different time windows. We find some evidence for negative announcement effects over the whole sample period, but little evidence for negative announcement effects for equity issuances which took place during the period of the Capital Exercise, especially for equity issuances from Capital Exercise banks. The absence of negative announcement effects for Capital Exercise banks could be due to the fact that investors are presumably aware that banks are required to increase their capital ratios by the EBA, which possibly reduces the negative signaling effect of an equity issuance. However, it is difficult to draw a strong conclusion from this analysis, since seasoned equity issuances in the wake of the Capital Exercise were rare. For the bond price event study, we follow Bessembinder, Kahle, Maxwell, and Xu (2009) and compute the market value-weighted average bond return at the bank level and use the matching portfolio approach to calculate abnormal bond returns. The matching portfolio approach matches bonds based on two primary risk factors: default risk (proxied by the bond rating) and the time to maturity. The abnormal return for bond i is then calculated by deducting the expected returns of the matched bond portfolio for bond $i$ from the observed return of bond $i$. Panel B of Table A9 reports the results of the bond price event study for different time windows. We do not find any significant abnormal bond returns around the announcement dates of seasoned equity offerings. 


\section{Table A9}

\section{Cumulative Abnormal Returns Around Seasoned Equity Offerings}

This table shows the average cumulative abnormal stock and bond returns around banks' seasoned equity offering announcements. Panel A presents the mean and median Cumulative Abnormal Stock Returns, CAR $(i j)$ over days $i$ to date $j$ relative to the bank SEO announcements, segregated into announcement made by capital exercise and control group banks for the sample period and announcements during the capital exercise. The market model uses MSCI Europe Financial index returns. Panel B presents the mean and median Cumulative Abnormal Bond Returns, CAR $(i j)$ over days $i$ to date $j$ relative to the bank SEO announcements, segregated into announcement made by capital exercise and control group banks for the sample period and announcements during the capital exercise. We used the matched Bond Portfolio Approach to calculate the abnormal bond returns. $* * *, * *, *$ respectively denote significantly different from zero at the $1 \%, 5 \%$, and $10 \%$ significance level based on Welch's t-test.

Window

Full Sample: 2009-2013

Capital Exercise: 2011:Q3-2012:Q2

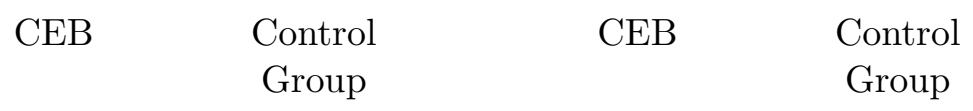

Panel A: Cumulative Abnormal Stock Returns Around Seasoned Equity Offerings

$\begin{array}{clcccc} & \text { N } & 47 & 32 & 7 & 6 \\ \text { CAR }(-1,0) & \text { Mean } & -1.02 & -1.83^{*} & -0.41 & -1.31 \\ & \text { Median } & -0.39 & -0.70 & 1.10 & 0.27 \\ & & & & -1.05 & -4.69^{* *} \\ \text { CAR }(0,1) & \text { Mean } & -1.81^{* *} & -3.48^{* * *} & 0.15 & -3.59 \\ & \text { Median } & -1.72 & -1.58 & & -2.36 \\ \text { CAR }(-1,1) & \text { Mean } & -1.72^{* *} & -3.06^{* * *} & -0.74 & -0.27 \\ & \text { Median } & -0.98 & -1.27 & -1.04 & \\ & & & & & -5.13 \\ \text { CAR }(-3,3) & \text { Mean } & -2.17^{* *} & -3.08^{*} & 1.24 & -5.75\end{array}$

Panel B: Cumulative Abnormal Bond Returns Around Seasoned Equity Offerings

$\begin{array}{llcccc} & \text { N } & 47 & 32 & 7 & 6 \\ & & & & & -0.03 \\ \text { CAR }(-1,0) & \text { Mean } & -0.02 & 0.02 & -0.11 & -0.06 \\ & \text { Median } & 0.00 & -0.02 & & \\ & & & & 0.08 & 0.00 \\ \text { CAR }(0,1) & \text { Mean } & 0.00 & 0.09 & -0.07 & 0.10 \\ & \text { Median } & 0.00 & -0.05 & & -0.08 \\ \text { CAR (-1,1) } & \text { Mean } & -0.04 & 0.05 & -0.01 & 0.00 \\ & \text { Median } & 0.00 & -0.08 & & -0.50 \\ \text { CAR }(-3,3) & \text { Mean } & -0.09 & -0.06 & -0.01 & -0.72\end{array}$


However, if markets are not fully efficient and if new information is not immediately and correctly priced in the market, then there might be long-term abnormal stock and bond returns (Eberhart and Siddique, 2002). We therefore compare the long-term stock performance of Capital Exercise banks which issued equity relative to the MSCI Europe Financials Index and the longterm performance of the banks' market value-weighted bond portolios relative to their matching bond portfolios. We investigate six different event time horizons from 30 days to 300 days after a bank's equity issuance. The results are presented in Table A10. As can be seen in Column 5, we find significant abnormal positive bond returns of up to 20 percentage points for Capital Exercise banks which issued equity during the period of the capital exercise over an event time horizon of 300 days. Moreover, as can be seen in Column 7, we find positive but not significant abnormal stock returns for those banks over the same time horizon. We interpret these findings as suggestive evidence that bondholders benefited disproportionately from the equity issuances of Capital Exercise banks. Thus, our short-term and long-term event study results suggest that debt overhang and not asymmetric information is the underlying economic reason for why Capital Exercise banks were reluctant to issue equity. However overall, we feel that only little can be concluded from this event study analysis, simply due to the low frequency of seasoned equity offerings, in particular by Capital Exercise Banks. 
Table A10

\section{Long-Term Abnormal Bond and Stock Returns in Event Time}

This table shows the long-term abnormal bond and stock returns in event time of Capital Exercise banks which issued equity.

Full Sample: 2009-2013

Abn. Bond Ret.

(1)

Days

$\mathrm{N}$

$\vartheta$ $\underline{-}$

A

(3)

Mean Median

32

32

$-3.56$

$-2.92$

$-2.36$

0.77

2.45

$-4.01^{* *}$
-0.92
-3.71
-1.99
4.40

Capital Exercise: 2011:Q3-2012:Q2

\begin{tabular}{ccccc}
\multicolumn{2}{c}{ Abn. Bond Ret. } & & \multicolumn{2}{c}{ Abn. Stock Ret. } \\
\cline { 1 - 2 } Mean & $(6)$ & & $(7)$ & $(8)$ \\
\end{tabular}

6

6

5

5

\subsection{9}

6.30

9.26

$15.70^{* *}$

$19.46^{* *}$
0.41

2.39

$5.38^{* *}$

$15.92^{\text {** }}$

22.28

$\begin{array}{cc}5 & 5 \\ -9.95 & -3.46 \\ -3.38 & 3.93 \\ 1.79 & 6.37 \\ 11.12 & 20.91 \\ 14.47 & 15.53\end{array}$




\section{Extended Loan-Level Analysis: Long-Run Adjustments in Banks' Credit Supply}

Our loan-level analysis investigates a time window of four quarters after the capital exercise (2012Q3-2013Q2) and thus focuses on the short-term adjustments of banks' credit supply in response to higher capital requirements. While a full-fledged analysis of the long-run effects of higher capital requirements is beyond the scope of this paper, we do provide some evidence for such potential long-run effects below. Figure A4 extends the graphical analysis of Figure 6 in Section III.B until 2016-Q2 and shows the trends in outstanding syndicated loan volumes for Capital Exercise banks and control group banks relative to 2011-Q2, the quarter immediately prior to the capital exercise.

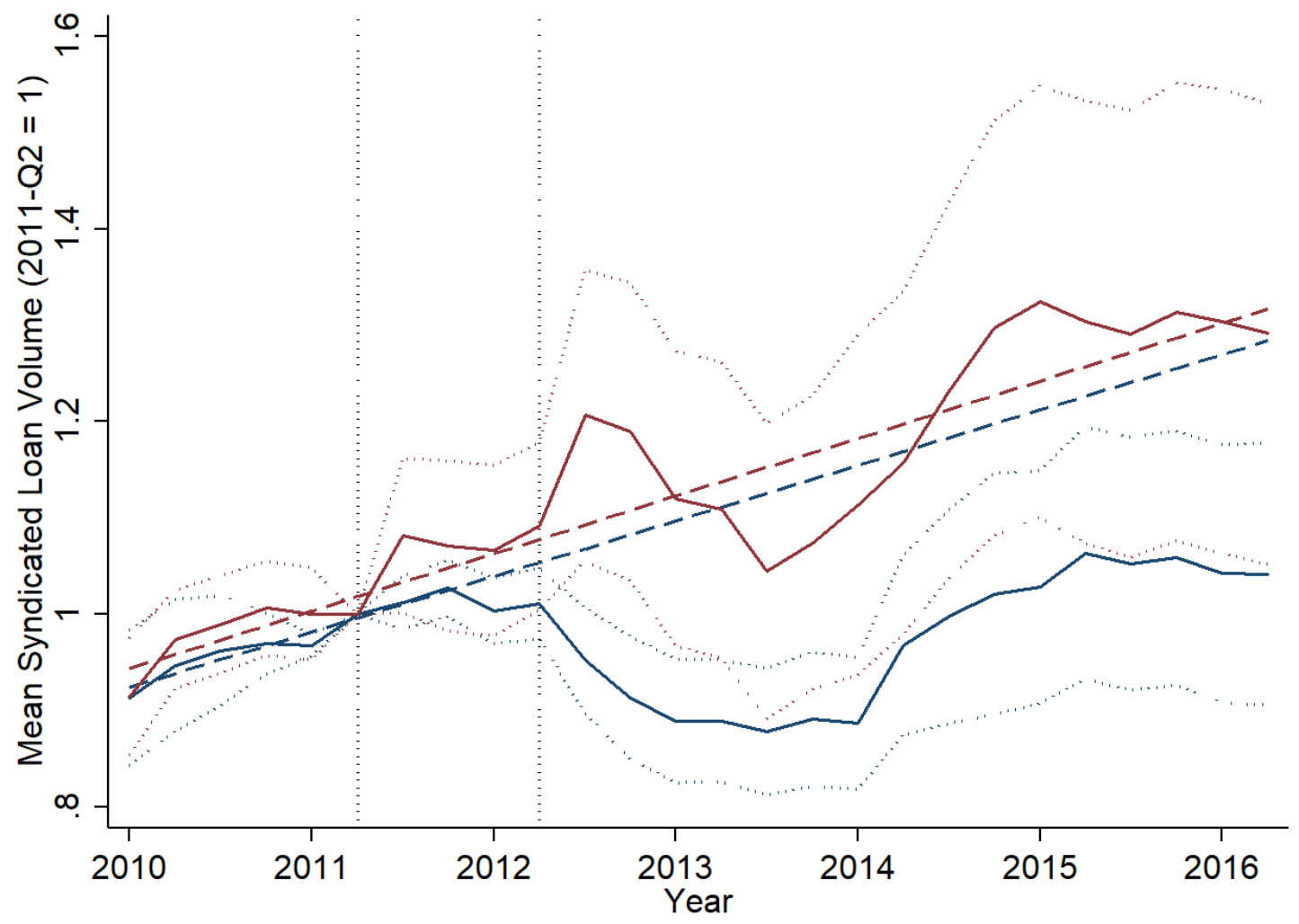

Figure A4. Syndicated Lending Over Time until 2016-Q2. This figure shows the loan volume of Capital Exercise banks (solid blue line) and Non-Capital Exercise banks (solid red line) in the syndicated loan market over the period 2010Q1-2016Q2, normalized to one in 2011Q2. The two dashed vertical lines mark 2011Q2 and 2012Q2, the years immediately before and after the capital exercise. The dashed red and blue lines indicate the extrapolated pre-treatment trends and the dotted lines indicated the $95 \%$ confidence intervals. 
As in, Figure 6 in Section III.B, loan volumes of Capital Exercise banks start to stagnate and then decrease after the capital exercise, while loan volumes for banks in the matched control group keep increasing. The long-run analysis reveals that this gap in outstanding syndicated loan volumes remains persistent until 2016-Q2, a full four years after the end of the capital exercise. However, Figure A4 also shows that this gap does not appear to widen much further after 2014.

To further analyze potential long-run effects, we extend the time window of the loan-level analysis until 2016-Q2 and re-estimate the regression specification from Equation (1) in Section II.B:

$$
\Delta \log \text { Loan Exposure } \text { Eij }=\beta \cdot \mathrm{CEB}_{b i}+\gamma \cdot X_{b i}+\eta_{i}+\eta_{j}+\epsilon_{b i j}
$$

where again the variable $C E B_{b i}$ takes on the value of 1 if the bank is a Capital Exercise bank, and 0 otherwise; $X_{b i}$ is a vector of bank characteristics as of 2010 (log total assets, core tier 1 ratio, customer loans as a share of total assets, net interest income as a share of total operating revenue, depository funding as a share of total assets, and net income over total assets); $\eta_{i}$ are bank home country fixed effects, and $\eta_{j}$ firm-cluster fixed effects.

For the dependent variable Log Loan Exposure $_{b i j}$, we now compute the change in loan exposures of bank $b$ in country $i$ to firm cluster $j$ between the four quarters before the EBA capital exercise (2010Q3-2011Q2) and four different four-quarter periods after the capital exercise (2012Q3-2013Q2; 2013Q3-2014Q2; 2014Q3-2015Q2; 2015Q3-2016Q2). These sequential regressions of the endogenous variable shifted ahead in time are in spirit of a local projection method (Jordà, 2005).

Table A11 presents the results of this local projection difference-in-difference regression analysis. The first column is equivalent to column 5 in Table $\mathrm{X}$ in Section III.B. ${ }^{29}$ The next three columns then show the results for the three sequential post-treatment periods. The gap in outstanding loan volumes increases even further from 21 percent in the period between 2012-Q3 to 2013-Q2 to 27 percent in the period between 2013-Q3 to 2014-Q2. In the two following years, the gap does not

\footnotetext{
${ }^{29}$ Note that the coefficients slightly differ between the two tables. For the long-run analysis, we downloaded a new vintage of the Thomson Reuters LPC Dealscan database in which information on some loan facilities is revised compared to the older vintage. We contacted Thomson Reuter regarding this issue and received the following answer: "Due to the private nature of the syndicated bank loan market and the way in which the syndication process works for bank loans, information on each loan is not always complete. In most instances, relevant information becomes available throughout the loans syndication as terms are being negotiated. Thomson Reuters LPC will capture and report on information that is verified by market sources. Though rare, there may be instances where certain Terms and Conditions were reported incorrectly that may require us to update them. There may also be instances where a loan was amended and in the process of verifying those changes, updated information pertaining to the origination of the loan may be discovered and captured."
} 
increase further and exhibits a magnitude of 29 percent in the period between 2014-Q3 to 2015-Q2 and of 27 percent in the period between 2015-Q3 to 2016-Q2. Thus, our long-run analysis suggests that there is no further deterioration in the credit supply of Capital Exercise banks after two years after the Capital Exercise. However, our analysis also suggests that Capital Exercise banks do not offset their reduction in credit supply in the long run and thus, the gap in outstanding syndicated loan volumes remains persistent until 2016-Q2, a full four years after the end of the capital exercise.

Table A11

\section{Syndicated Lending: Intensive Margin (Long-Run Adjustments)}

This table presents the estimation results of the long-run adjustments in lending following the 2011 EBA capital exercise:

$$
\Delta \log \text { Loan Exposure } \text { Eij }=\beta \cdot \mathrm{CEB}_{b i}+\gamma \cdot X_{b i}+\eta_{i}+\eta_{j}+\epsilon_{b i j}
$$

where $\Delta \log$ Loan $_{\text {Exposure }}$ bij is the change in loan exposure of bank $b$ in country $i$ to firm cluster $j$ between the four quarters before the EBA capital exercise (2010Q3 - 2011Q2) and four different four-quarter periods after the capital exercise (2012Q3-2013Q2; 2013Q3-2014Q2; 2014Q3-2015Q2; 2015Q3-2016Q2). The variable $C E B_{b i}$ takes on the value of 1 if the bank is a Capital Exercise bank, and 0 otherwise. Bank characteristics include: Log Total Assets, Core Tier 1 Ratio, Customer Loans / Total Assets, Net Interest Income / Operating Revenue, Total Deposits / Total Assets, and Net Income / Total Assets, all as of 2010. $\eta_{j}$ are Borrower Home Country $\times$ Industry (firm cluster) fixed effects and $\eta_{i}$ are bank home country fixed effects. Standard errors are clustered at the bank level. *, **, and $* * *$ indicate statistical significance at the $10 \%, 5 \%$, and $1 \%$ level respectively.

$\begin{array}{lcccc}\text { Post Period } & \text { 12Q3-13Q2 } & \text { 13Q3-14Q2 } & \text { 14Q3-15Q2 } & \text { 15Q3-16Q2 } \\ \text { CEB } & -0.21^{* * *} & -0.27^{* * *} & -0.29^{* *} & -0.27^{* *} \\ & (0.06) & (0.09) & (0.11) & (0.12) \\ & & & & \\ & & & & \text { YES } \\ \text { Bank Home Country FE } & \text { YES } & \text { YES } & \text { YES } & \text { YES } \\ \text { Bank Characteristics } & \text { YES } & \text { YES } & \text { YES } & \text { YES } \\ \text { Borrower Home Country } \times \text { Industry FE } & \text { YES } & \text { YES } & \text { YES } & 45 \\ & & & & 26 \\ \text { Capital Exercise Banks } & 45 & 45 & 45 & 26 \\ \text { Control Group Banks } & 27 & 26 & & 0.26 \\ & & & 0.25 & 2,011 \\ \text { Adjusted } R^{2} & 0.28 & 0.23 & 2,051 & \\ \text { Observations } & 2,169 & 2,091 & & \\ & & & \end{array}$




\section{Table A12}

\section{Syndicated Lending: Intensive Margin (Credit Lines \& Term Loans)}

This table presents the estimation results of the change in lending around the 2011 EBA capital exercise from Table $\mathrm{X}$ separtely for credit lines and term loans. The dependent variable $\Delta \log$ Loan Exposure $_{b i j}$ is the change in credit line (term loan) exposure of bank $b$ in country $i$ to firm cluster $j$ between the four quarters before the EBA capital exercise (2010Q3 - 2011Q2) and the four quarters after the capital exercise (2012Q3 - 2013Q2). The variable $C E B_{b i}$ takes on the value of 1 if the bank is a Capital Exercise bank, and 0 otherwise. Bank characteristics include: Log Total Assets, Core Tier 1 Ratio, Customer Loans / Total Assets, Net Interest Income / Operating Revenue, Total Deposits / Total Assets, and Net Income / Total Assets, all as of 2010. $\eta_{j}$ are Borrower Home Country $\times$ Industry (firm cluster) fixed effects and $\eta_{i}$ are bank home country fixed effects. The intensive margin sample includes country-industry firm clusters to which banks lend before and after the capital exercise. Standard errors are clustered at the bank level. *, **, and *** indicate statistical significance at the $10 \%, 5 \%$, and $1 \%$ level respectively.

Panel A: Change in Log Credit Line Exposure

$\begin{array}{lccccc}\text { CEB } & -0.33 & -0.25^{* *} & -0.29^{* * *} & -0.29^{* * *} & -0.30^{* * *} \\ & (0.29) & (0.10) & (0.09) & (0.09) & (0.09) \\ & & & & & \\ \text { Bank Home Country FE } & \text { YES } & \text { YES } & \text { YES } & \text { YES } & \text { YES } \\ \text { Bank Characteristics } & & \text { YES } & \text { YES } & \text { YES } & \text { YES } \\ \text { Borrower Home Country FE } & & & \text { YES } & \text { YES } & \\ \text { Industry FE } & & & \text { YES } & \\ \text { Borrower Home Country } \times \text { Industry FE } & & & & & \text { YES } \\ \text { Capital Exercise Banks } & & & & & \\ \text { Control Group Banks } & 45 & 45 & 45 & 45 & 45 \\ \text { Adjusted } R^{2} & 27 & 27 & 27 & 27 & 27 \\ \text { Observations } & 0.02 & 0.03 & 0.07 & 0.09 & 0.24 \\ & 2,177 & 2,177 & 2,177 & 2,177 & 2,177\end{array}$

Panel B: Change in Log Term Loan Exposure

$\begin{array}{lccccc}\text { CEB } & -0.10 & -0.08 & -0.09 & -0.09 & -0.10 \\ & (0.07) & (0.10) & (0.09) & (0.09) & (0.08) \\ & & & & & \\ \text { Bank Home Country FE } & \text { YES } & \text { YES } & \text { YES } & \text { YES } & \text { YES } \\ \text { Bank Characteristics } & & \text { YES } & \text { YES } & \text { YES } & \text { YES } \\ \begin{array}{l}\text { Borrower Home Country FE } \\ \text { Industry FE }\end{array} & & \text { YES } & \text { YES } & \\ \text { Borrower Home Country } \times \text { Industry FE } & & & \text { YES } & \\ & & & & & \text { YES } \\ \text { Capital Exercise Banks } & 45 & 45 & 45 & 45 & 45 \\ \text { Control Group Banks } & 27 & 27 & 27 & 27 & 27 \\ & & & & & \\ \text { Adjusted } R^{2} & 0.02 & 0.03 & 0.06 & 0.08 & 0.27 \\ \text { Observations } & 2,177 & 2,177 & 2,177 & 2,177 & 2,177\end{array}$




\section{Extended Loan-Level Analysis: Home Bias Test}

(Giannetti and Laeven, 2012) find that the collapse of the global market for syndicated loans during financial crises can in part be explained by a flight home effect whereby lenders rebalance their loan portfolios in favor of domestic borrowers. Table A13 tests for such a "home bias" effect induced by the 2011 EBA capital exercise. We re-estimate the regression specification from Equation (1) in Section II.B and additionally include an interaction term of the variable $C E B$ with the variable Foreign Lending, which takes on the value of one if a firm cluster is not based at the home country of bank $i$, and zero otherwise. The results in Table A13 provide no evidence for such a "home bias" effect.

Table A13

Syndicated Lending: Intensive Margin (Home Bias Test)

\begin{tabular}{lccccc}
\hline CEB & & & & & \\
& -0.09 & $-0.14^{*}$ & $-0.15^{*}$ & $-0.15^{*}$ & $-0.16^{* *}$ \\
& $(0.05)$ & $(0.08)$ & $(0.08)$ & $(0.08)$ & $(0.07)$ \\
CEB $\times$ Foreign Lending & & & & & \\
& 0.00 & -0.01 & -0.02 & -0.02 & -0.01 \\
& $(0.04)$ & $(0.04)$ & $(0.03)$ & $(0.03)$ & $(0.03)$ \\
Bank Home Country FE & YES & YES & YES & YES & YES \\
Bank Characteristics & & YES & YES & YES & YES \\
Borrower Home Country FE & & & YES & YES & \\
Industry FE & & & & YES & \\
Borrower Home Country $\times$ Industry FE & & & & & YES \\
Capital Exercise Banks & & & & & 45 \\
Control Group Banks & 45 & 45 & 45 & 45 & 27 \\
Adjusted $R^{2}$ & 27 & 27 & 27 & 27 & 27 \\
Observations & & & & & \\
& 0.02 & 0.03 & 0.07 & 0.09 & 0.25 \\
& 2,177 & 2,177 & 2,177 & 2,177 & 2,177 \\
\hline
\end{tabular}




\section{Extended Loan-Level Analysis: Extensive Margin}

In the loan-level part, we studied the intensive margin sample of country-industry firm clusters to which Capital Exercise banks lent both before and after the capital exercise. We now also provide results for the extensive margin sample and study whether banks stopped or started lending to specific country-industry firm clusters. To investigate this, we estimate the following regression specification:

$$
Y_{b i j}=\alpha+\beta \cdot \mathrm{CEB}_{b i}+\gamma X_{b i}+\eta_{i}+\eta_{j}+\epsilon_{b i j}
$$

where $Y_{b i j}$ is either the dummy variable Exit $_{b i j}$, which takes on the value of 1 if bank $b$ from country $i$ stopped lending to firm cluster $j$ after the capital exercise, and 0 otherwise; or the dummy variable Entry $y_{i j}$, which takes on the value of 1 if bank $b$ from country $i$ started lending to firm cluster $j$ after the capital exercise, and 0 otherwise. The variable $C E B_{b i}$ takes on the value of 1 if the bank is part of the EBA capital exercise, and 0 otherwise. In addition, the specification includes bank characteristics as of 2010 (log total assets, core tier 1 ratio, customer loans as a share of total assets, net interest income as a share of total operating revenue, depository funding as a share of total assets, and net income over total assets) and firm cluster fixed effects $\eta_{j}$, which absorb all cluster-specific credit demand shocks.

The first three columns of Table A14 provide evidence that Capital Exercise banks did not stop lending to specific country-industry firm clusters after the capital exercise. The fourth column suggests that Capital Exercise banks may have been less likely to start lending to new clusters, however this result becomes insignificant after controlling for bank characteristics and borrower country-industry fixed effects. The results therefore show that the EBA capital exercise primarily affected lending on the intensive margin. 


\section{Table A14 \\ Syndicated Lending: Extensive Margin}

This table presents the estimation results of whether banks started or stopped lending to countryindustry firm clusters around the 2011 EBA capital exercise from Equation ?? in Section ??:

$$
Y_{b i j}=\alpha+\beta \cdot \mathrm{CEB}_{b i}+\gamma X_{b i}+\eta_{i}+\eta_{j}+\epsilon_{b i j}
$$

where $Y_{b i j}$ is either the dummy variable $E_{x i t_{b i j}}$, which takes on the value of 1 if bank $b$ from country $i$ stopped lending to firm cluster $j$ after the capital exercise, and 0 otherwise; or the dummy variable $E_{\text {Entr }}$ bij, which takes on the value of 1 if bank $b$ from country $i$ started lending to firm cluster $j$ after the capital exercise, and 0 otherwise. The variable $C E B_{b i}$ takes on the value of 1 if the bank is part of the EBA capital exercise, and 0 otherwise. $\eta_{j}$ are Borrower Home Country x Industry (firm cluster) fixed effects and $\eta_{i}$ are bank home country fixed effects. Bank characteristics include: Total Assets, CT1 Capital Ratio, Total Deposits / TA, Customer Loans / TA, Net Interest, Income / Operating Revenue, and Net Income / TA, measured in the before period. Standard errors are clustered at the bank level. *, ${ }^{* *}$, and ${ }^{* * *}$ indicate statistical significance at the $10 \%, 5 \%$, and $1 \%$ level respectively.

\begin{tabular}{|c|c|c|c|c|c|c|}
\hline \multirow[t]{2}{*}{ Dependent Variable } & \multicolumn{3}{|c|}{ Exit } & \multicolumn{3}{|c|}{ Entry } \\
\hline & (1) & $(2)$ & $(3)$ & $(4)$ & (5) & (6) \\
\hline $\mathrm{CEB}$ & $\begin{array}{l}-0.01 \\
(0.02)\end{array}$ & $\begin{array}{l}0.05^{*} \\
(0.03)\end{array}$ & $\begin{array}{c}0.04 \\
(0.03)\end{array}$ & $\begin{array}{l}-0.07^{* *} \\
(0.02)\end{array}$ & $\begin{array}{c}-0.05^{*} \\
(0.03)\end{array}$ & $\begin{array}{l}-0.03 \\
(0.02)\end{array}$ \\
\hline $\begin{array}{l}\text { Bank Home Country FE } \\
\text { Bank Characteristics } \\
\text { Borrower Country } \times \text { Industry } \\
\text { FE }\end{array}$ & YES & $\begin{array}{l}\text { YES } \\
\text { YES }\end{array}$ & $\begin{array}{l}\text { YES } \\
\text { YES } \\
\text { YES }\end{array}$ & YES & $\begin{array}{l}\text { YES } \\
\text { YES }\end{array}$ & $\begin{array}{l}\text { YES } \\
\text { YES } \\
\text { YES }\end{array}$ \\
\hline $\begin{array}{l}\text { Capital Exercise Banks } \\
\text { Control Group Banks }\end{array}$ & $\begin{array}{l}45 \\
45\end{array}$ & $\begin{array}{l}45 \\
45\end{array}$ & $\begin{array}{l}45 \\
45\end{array}$ & $\begin{array}{l}45 \\
50\end{array}$ & $\begin{array}{l}45 \\
50\end{array}$ & $\begin{array}{l}45 \\
50\end{array}$ \\
\hline $\begin{array}{l}\text { Adjusted } R^{2} \\
\text { Number of Observations }\end{array}$ & $\begin{array}{c}0.02 \\
2,344\end{array}$ & $\begin{array}{c}0.02 \\
2,344\end{array}$ & $\begin{array}{c}0.25 \\
2,344\end{array}$ & $\begin{array}{c}0.06 \\
2,345\end{array}$ & $\begin{array}{c}0.06 \\
2,345\end{array}$ & $\begin{array}{c}0.28 \\
2,345\end{array}$ \\
\hline
\end{tabular}


Table A15

\section{Firm-Level Regression Analysis}

This table presents the estimation results for the following difference-in-difference regression:

$$
\Delta Y_{j c i}=\alpha+\beta \times \text { CEB Borrowing Share }{ }_{j c i}+\sum_{k} \theta^{k} X_{j c i}+\eta_{c}+\eta_{i}+\epsilon_{j c i}
$$

where $\Delta Y_{j c i}$ is the change in the firm outcome variable of firm $j$ in country $c$ in industry $i$. The variable CEB Borrowing Share ${ }_{j c i}$ is the share of borrowing in the syndicated loan market obtained by firm $j$ from Capital Exercise banks in the period prior to the capital exercise. In our preferred specification the paper includes firm-level control variables $X_{j c i}$ (i.e., Log Total Assets, Tangibility, Cash Flow/TA, Net Worth, EBITDA/TA, Leverage), firm country fixed effects $\eta_{c}$, and industry fixed effects $\eta_{i}$. The firm outcome variable $\Delta Y_{j c i}$ is the change in the logarithm of total assets in Panel A, the change in the logarithm of fixed assets in Panel B, and the change in the logarithm of sales in Panel C. Standard errors are clustered at the firm-country level. *, **, and *** indicated statistical significance at the $10 \%, 5 \%$, and $1 \%$ level respectively.

\begin{tabular}{|c|c|c|c|c|c|c|}
\hline Panel A: $\Delta$ Log Total Assets & $(1)$ & $(2)$ & $(3)$ & $(4)$ & $\begin{array}{l}(5) \\
\text { Non-Listed } \\
\text { Firms }\end{array}$ & $\begin{array}{l}(6) \\
\text { Listed } \\
\text { Firms }\end{array}$ \\
\hline CEB Borrowing Share & $\begin{array}{c}-0.09^{* * *} \\
(0.02)\end{array}$ & $\begin{array}{c}-0.07^{* * *} \\
(0.02)\end{array}$ & $\begin{array}{c}-0.08^{* * *} \\
(0.02)\end{array}$ & $\begin{array}{c}-0.08^{* * *} \\
(0.02)\end{array}$ & $\begin{array}{c}-0.09^{* * *} \\
(0.03)\end{array}$ & $\begin{array}{l}-0.02 \\
(0.05)\end{array}$ \\
\hline $\begin{array}{l}\text { Firm-Level Controls } \\
\text { Borrower Home Country FE } \\
\text { Industry FE }\end{array}$ & & YES & $\begin{array}{l}\text { YES } \\
\text { YES }\end{array}$ & $\begin{array}{l}\text { YES } \\
\text { YES } \\
\text { YES }\end{array}$ & $\begin{array}{l}\text { YES } \\
\text { YES } \\
\text { YES }\end{array}$ & $\begin{array}{l}\text { YES } \\
\text { YES } \\
\text { YES }\end{array}$ \\
\hline $\begin{array}{l}\text { Number of Firms } \\
\text { Panel B: } \Delta \text { Log Fixed Assets }\end{array}$ & 2,087 & 2,087 & 2,087 & 2,087 & 1,529 & 558 \\
\hline CEB Borrowing Share & $\begin{array}{c}-0.13^{* * *} \\
(0.03)\end{array}$ & $\begin{array}{c}-0.10^{* * *} \\
(0.03)\end{array}$ & $\begin{array}{c}-0.10^{* * *} \\
(0.03)\end{array}$ & $\begin{array}{c}-0.10^{* * *} \\
(0.03)\end{array}$ & $\begin{array}{c}-0.13^{* * *} \\
(0.03)\end{array}$ & $\begin{array}{l}-0.05 \\
(0.04)\end{array}$ \\
\hline $\begin{array}{l}\text { Firm-Level Controls } \\
\text { Borrower Home Country FE } \\
\text { Industry FE }\end{array}$ & & YES & $\begin{array}{l}\text { YES } \\
\text { YES }\end{array}$ & $\begin{array}{l}\text { YES } \\
\text { YES } \\
\text { YES }\end{array}$ & $\begin{array}{l}\text { YES } \\
\text { YES } \\
\text { YES }\end{array}$ & $\begin{array}{l}\text { YES } \\
\text { YES } \\
\text { YES }\end{array}$ \\
\hline $\begin{array}{l}\text { Number of Firms } \\
\text { Panel C: } \Delta \text { Log Sales }\end{array}$ & 2,087 & 2,087 & 2,087 & 2,087 & 1,529 & 558 \\
\hline CEB Borrowing Share & $\begin{array}{c}-0.08^{* * *} \\
(0.03)\end{array}$ & $\begin{array}{c}-0.08^{* * *} \\
(0.03)\end{array}$ & $\begin{array}{c}-0.09^{* * *} \\
(0.03)\end{array}$ & $\begin{array}{c}-0.07^{*} \\
(0.03)\end{array}$ & $\begin{array}{c}-0.08^{* *} \\
(0.04)\end{array}$ & $\begin{array}{l}-0.14 \\
(0.09)\end{array}$ \\
\hline $\begin{array}{l}\text { Firm-Level Controls } \\
\text { Borrower Home Country FE } \\
\text { Industry FE }\end{array}$ & & YES & $\begin{array}{l}\text { YES } \\
\text { YES }\end{array}$ & $\begin{array}{l}\text { YES } \\
\text { YES } \\
\text { YES }\end{array}$ & $\begin{array}{l}\text { YES } \\
\text { YES } \\
\text { YES }\end{array}$ & $\begin{array}{l}\text { YES } \\
\text { YES } \\
\text { YES }\end{array}$ \\
\hline Number of Firms & 2,087 & 2,087 & 2,087 & 2,087 & 1,529 & 558 \\
\hline
\end{tabular}

